Journal of History Culture and Art Research (ISSN: 2147-0626)

Tarih Kültür ve Sanat Araştırmaları Dergisi

Vol. 8, No. 3, September 2019

\title{
DOI: 10.7596/taksad.v8i3.2212
}

Citation: Yüksel, M. (2019). Pierre Bourdieu ve Spor Sosyolojisine Katkıları. Journal of History Culture and Art Research, 8(3), 495-515. doi:http://dx.doi.org/10.7596/taksad.v8i3.2212

\section{Pierre Bourdieu ve Spor Sosyolojisine Katkıları}

\author{
Pierre Bourdieu and Contributions to Sociology of Sport
}

Murat Yüksel ${ }^{1}$

\begin{abstract}
This study aims to introduce Pierre Bourdieu's life, works, sociology, concepts he created and his contributions to the sociology of sports. The research was conducted with the literature search method. Bourdieu is one of the important sociologists of modern French sociology. His sociological point of view, qualified works and the theories/concepts he developed have carried him to the peak of intellectual life. In his academic life, subjects notably culture, education, art, politics, intellectuals, class, power, state, poverty, gender, economic-political, media and sociology of science, he has succeeded in enriching his sociology as a sociologist who has written many important works on many subjects and constantly creating new concepts and theories. The most striking feature of his sociology is to benefit from statistical methods and survey techniques. When Bourdieu's works are examined, it is seen that none of these new concepts created contradicts the ones he has produced before, there is no change in his basic point of view or acceptance and he carried his own sociology further. Another importance of Bourdieu's sociology is related to the in-depth analysis of the theories or concepts produced by empirical studies and demonstration of responses in practice. In addition, his sociology is a sociology that raises on the ideas of classical sociologists, avoids structure-individual dualism, combines theory and practice, and attempts to reveal the relationship between the social structure and the symbolic structure. The most important concepts of Bourdieu are habitus, field and capital. He tries to understand social hierarchy, domination relations and class differences through these concepts. It is seen that sports play an important role in the analysis of his theories or concepts. In general, it is important to monitor the fundamental dynamics of the field in the field of sport, to test the results of the habitus and capital differences directly in the sport, and also to show that the judgment or differences of taste appear as differences in sportive trends. Therefore, Bourdieu, both enabled the understanding of the social field and contributed to the development of sports sociology by making sociological analyzes on sports.
\end{abstract}

Keywords: Pierre Bourdieu, Sociology of Sport, Field, Habitus, Capital.

\footnotetext{
${ }^{1}$ Dr. Öğr. Üyesi, Ordu Üniversitesi, Fen-Edebiyat Fakültesi, Sosyoloji Bölümü. E-mail: bdmurat81@hotmail.com
} 
Bu çalışma Pierre Bourdieu'nün hayatını, eserlerini, sosyolojisini, ürettiği kavramları ve spor sosyolojine katkılarını tanıtmayı amaçlamaktadır. Araştırma literatür taraması yöntemiyle yapıımıştır. Bourdieu, çağdaş Fransız sosyolojisinin önemli sosyologlarından biridir. Sosyolojik bakışı, nitelikli eserleri ve geliştirdiği kuramlar/kavramlar onu entelektüel hayatın zirvesine taşımıştır. Akademik hayatında kültür, eğitim, sanat, siyaset, entelektüeller, sınıf, güç, devlet, sefalet, toplumsal cinsiyet, ekonomi-politik, medya ve bilim sosyolojisi gibi konular başta olmak üzere, daha birçok konuda oldukça önemli eserlere imza atan bir sosyolog olarak ve sürekli yeni kavramlar ve teoriler üreterek sosyolojisini zenginleştirmeyi başarmıştır. Onun sosyolojisinin dikkat çekici en temel özelliği, istatistiki yöntemlerden ve anket tekniğinden yararlanmaktır. Bourdieu'nün eserlerine bakıldığında, ürettiği bu yeni kavramların hiçbirisinin daha önce ürettikleri ile çelişmediği, temel bakış açısında ya da kabullerinde bir değişiklik olmadığı ve kendine özgü sosyolojisini daha ileri taşıdığı görülmektedir. Bourdieu sosyolojisinin bir diğer önemi, ürettiği kuram ya da kavramların ampirik çalışmalarla derinlemesine analizinin yapılarak, pratikte karşılıkların gösterilmesiyle ilişkilidir. Ayrıca, onun sosyolojisi, klasik sosyologların düşünceleri üzerinde yükselen, yapı-birey düalizminden uzak duran, teori ve pratiği bir araya getiren ve sosyal yapıyla sembolik yapı arasındaki ilişkileri açığa çıkarmaya çalışan bir sosyolojidir. Bourdieu'nün en önemli kavramlarının başında habitus, alan ve sermaye gelir. Bu kavramlar üzerinden, toplumsal hiyerarşiyi, tahakküm ilişkilerini ve sınıf farklılıklarını anlamaya çalışır. Onun kuram ya da kavramlarının analizinde sporun da önemli bir yer tuttuğu görülür. Genel olarak alanın temel dinamiklerini spor alanında da izlemek, habitusun ve sermaye farklııklarının sonuçlarını doğrudan spor özelinde de test etmek ve aynı zamanda beğeni yargısının ya da farklııklarının sportif eğilimlerdeki farklılıklar olarak da ortaya çıkması önemlidir. Dolayısıyla Bourdieu, spor üzerinden sosyolojik analizler yaparak, hem toplumsal alanın anlaşılmasına olanak sağlamış hem de spor sosyolojisinin gelişmesine katkı sunmuştur.

Anahtar Sözcükler: Pierre Bourdieu, Spor Sosyolojisi, Alan, Habitus, Sermaye.

\section{Giriş}

Pierre Bourdieu çağdaş Fransız sosyolojisinin önde gelen isimlerinden biridir. XX. yüzyılın ikinci yarısından itibaren gelişen yeni Fransız sosyolojisine damga vuran sosyologlar arasında ön sıralarda yer alır. O, iktisadi ve kültürel sermayesi düşük bir aileden gelmesine rağmen, Fransa'nın en başarılı ve zeki insanlarının okuduğu College de France'a kadar yükselmeyi ve ülkenin en önemli entelektüelleri arasına girmeyi başarmıştır. Felsefe formasyonuna sahip olan Bourdieu, Cezayir tecrübesinden sonra, felsefeden koparak antropoloji ve sosyolojiye ilgi duymaya başlamıştır. Hem nitelik hem de nicelik açısından oldukça önemli eserlerin altına imza atmış olan Bourdieu, her zaman yeni kavram ya da teoriler üretmeyi başarmış ve sosyolojisini sürekli olarak geliştirmiştir. illk eseri olan, 1958 yılında yayınladığı Cezayir'in Sosyolojisi'nden, 2002 yılında vefat ettiği tarihe kadar yazdığı bütün eserlerin konularının süreç içerisinde değiştiği ve her eserinde zamanın temel sorunlarına dikkat çektiği görülmektedir.

Sosyolojiye Raymond Aron ile başlayan Bourdieu, klasik Fransız entelektüelinden farklı olarak, sosyolojisini geliştirirken ampirik araştırmalara önem vermiştir. 0 , istatistiki yöntemlerle Fransız teorik geleneğini birleştirmiş ve saha araştırmalarının sonucunda sosyolojiye yeni kuram ya da kavramlar kazandırmıştır. Sosyolojisinin temel özelliği, toplumsal hiyerarşiyi, hegemonik ilişkileri ve sınıf farklııklarını anlamaya çalışmasıdır. Bourdieu, sosyolojinin ya da sosyoloğun tarafsız olamayacağı düşünür ve sosyolojinin toplumdaki iktidar ilişkileri üzerinden, toplumsal yapıyı incelemesi gerektiğini ifade eder. Onun sosyolojisi, klasik sosyologların düşünceleri üzerinde yükselen, yapı-birey düalizminden uzak duran, teori ve pratiği bir araya getiren ve sosyal yapıyla sembolik yapı arasındaki ilişkileri açığa çıkarmaya çalışan bir sosyolojidir. Geliştirdiği teoriye yapısalcı inşacılık ismini vermiş ve bu teorisiyle, toplumsal yapı ile birlikte, bu yapıya bağlı simgesel bir yapının veya habitusun olduğunu 
söyleyerek, kendisini klasik yapısalcılardan ayırmıştır. Ayrıca Bourdieu, düşünümsellik olarak ifade ettiği kavramla, araştırmanın sürekli geri dönüşler yapılarak değerlendirilmesi ve bu kavram ekseninde araştırmacının kendisini de sürecin bir parçası olarak görmesini önerir. Ona göre bu yaklaşım araştırmacıya bireysel bir eylemin arkasındaki toplumsal nedenleri görme fırsatı verecektir.

Bourdieu, sosyoloji dünyasına birçok alan kazandırmış, yeni bir bakış açısı getirmiş ve yeni kavramlar/kuramlar geliştirmiş bir sosyologdur. Geliştirdiği kuram ya da kavramların başında habitus, alan ve sermaye gelmektedir. Bourdieu sosyolojisi, bireysel eylemler ile toplumun bireylerden beklediği davranışlar arasında nasıl bir ilişki olduğun belirlemeye çalışır. Bir diğer ifadeyle, bireysel eylemlerin arkasındaki temel mantığı anlamaya çalışır. Bunun için habitus kavramını geliştirmiştir. Habitus bireylerin içsel eğilimlerine vurgu yapan bir kavramdır. Habitus, toplumsal hayattaki hegemonik ilişkileri açıklamaya çalışır. Bourdieu'nün bir diğer kavramı olan alan ise, sosyal yapıda ortaya çıkan bütün ilişkilere atıf yapar. Ayrıca alan ve habitus birbirlerini karşılıklı olarak etkileyen yapılardır. Diğer önemli bir kavramı ise sermayedir. Sermaye hem bireylerin eylemlerini belirleyen hem de toplumsal yapıdaki tahakkümün ilişkilerini göstermeye çalışan bir kavramdır. İktisadi sermaye dışında, kültürel, sosyal ve simgesel olmak üzere dört farklı sermaye türünden bahseder. Bourdieu sermaye kavramı üzerinden, sosyolojik çözümlemelere girişir ve toplumda yer alan sosyal sınıflar üzerinde farklı hacimlerde ortaya çıktığını söyler ve bunun üzerinden sınıflar arası eylem farklııklarını anlamaya çalışır. Genel olarak bu kavramların hepsi, günümüzde sınırlarının oldukça belirsizleştiği sınıfları ve eğilimlerini anlamak açısından önemli fırsatlar verir. Bourdieu'nün üzerinde durduğu bir başka kavram ise sınıf habitusudur. Insanların toplumsal hayattaki bütün davranış farklılıkları, sahip olduğu sınıf habitusuna göre ortaya çıkar.

Bourdieu'nün geliştirdiği kavram ya da kuramların pratiğini, spor üzerinden de yapması ya da sporu kullanarak analiz etmesi, spor sosyolojisine önemli katkılar sağlamıştır. Sportif alanda ortaya çıkan bütün ilişkiler, bireylerin habitusuyla ya da sahip oldukları sermaye hacmi ve türü ile doğrudan ilişkilidir. Bir taraftan Bourdieu'nün kendisinin ürettiği kavramları spor aracılı̆̆ıyla analize tabi tutması, diğer taraftan başka teorisyenlerin de bu kavramları kullanarak spor üzerinde önemli çalışmalara imza atmaları ve çoğu zaman aynı bulgulara ulaşmaları, hem kavramların başarısına ve geçerliğine hem de spor sosyolojisinin gelişimine önemli katkılar sağladığı görülmektedir. Dolayısıyla genel anlamda alanın temel dinamiklerini spor alanında da izlemek, habitusun ve sermaye farklııklarının sonuçlarını doğrudan spor özelinde de test etmek ve aynı zamanda beğeni yargısının ya da farklılıklarının sportif eğilimlerdeki farklııklar olarak da ortaya çıkması önemlidir. Sonuç olarak, beden başta olmak üzere, tüm sportif pratiklerde bu farklııkların ya da ilişkilerin yansımalarını bulmak ya da spor üzerinden sosyoloji yapmak, spor sosyolojisinin gelişimi açısından tartışılmaz bir öneme sahiptir.

Bourdieu sosyolojisi ile ilgili ya da kavramları üzerinden Türkiye'de XXI. yüzyılın başlarından itibaren çok fazla yayın yapılmış olmasına rağmen, doğrudan spor sosyolojisine olan katkılarına dair çalışmalar oldukça sınırlı kalmıştır. Spor alanında son zamanlarda, doğrudan başlıkları bu kavramlar olmasa da alan, habitus, sermaye ya da beğeni farklııkları ekseninde yapılan çalışmalarda bir hareketlenme görülmektedir. Bu çalışmayla da alana (spor sosyolojisine) bir katkı sunmak hedeflenmektedir. Bu çalışma, Bourdieu sosyolojisinin ve geliştirdiği kavramların spor sosyolojisinin gelişimine önemli katkılar sağladığı varsayımına dayanır.

\section{Hayatı ve Eserleri}

Pierre Boudieu'nün mesleki kariyeri, çok nadir görülen yukarı doğru dikey hareketlilik örneğidir. Sıra dışı bir kültür ve sosyal kökenden gelmesine rağmen, Fransa'da entelektüel hayatın zirvesi olan College de France'a kadar yükselmiştir (Swartz, 2011: 31).

Bourdieu 1930 yılında, Fransa'nın güneybatısında Pireneler'de Denguin şehrinin Bern kasabasında, alt orta sınıf bir ailenin çocuğu olarak (babası köyün postacısı olan bir devlet memurudur) doğar. Zeki ve çalışkan bir öğrenci olarak, orta öğrenimini Paris'in ünlü Louis Le Grand lisesinde tamamladıktan 
sonra, felsefenin oldukça itibarlı olduğu bir dönemde, 1950'li yılların başında Fransa'nın prestijli okullarından Ecole Normale Superieure'e girer. Akademik anlamda elit bir okul olan Ecole Normale Superieure, öğretmen yetiştirmek için kurulsa da, daha sonra Fransız entelektüellerinin yetiştiği bir okul haline gelmiştir. Bourdieu bu okuldan felsefe derecesi alarak mezun olur. Felsefeye başladığı ilk yıllardan itibaren, zamanın egemen öğretisi olan "özne felsefesi"nden uzaklaşır ve "kavram felsefesi"ne yönelir. Ancak, mezun olduktan kısa bir süre sonra Durkheim ve Foucault gibi sosyal bilimlere döner. Zorunlu askerlik hizmeti nedeniyle gönderildiği Cezayir'deki sömürge yönetiminin ve savaşın korkunç yüzü ile karşılaşan Bourdieu, sömürgeci yönetim ile yerli halk arasında yaşanan çatışmaların neden olduğu sosyal yıkımları anlamak için etnoloji ve sosyolojiye yönelir. Dolayısıyla, "Cezayir'in Sosyolojisi" (1958), "Cezayir'de Emek ve İşçiler" (1963) ve "Köksüzleşmek: Cezayir'de Geleneksel Tarımın Krizi" (1964) isimli ilk kitapları, Cezayir'deki etnik grupların dağılımı ve kültürleri üzerinden, bağımsız bir Cezayir'in doğuşunu incelemek ve ona yardımcı olmak için, istatistiki yöntemlerden yararlanılarak yapılan ampirik çalışmalardır. Bourdieu sosyolojisinin en temel özelliği olan istatistiki yöntemlerden ve anket tekniğinden yararlanmak, bu eserlerinde açıkça görülmektedir (Amman, 1995: 112; Wacquant, 2010: 53-54; Swartz, 2011: 31; Jourdan \& Naulin, 2016: 7-8).

Bourdieu, 60'lı yılların başlarında Paris'e döner ve Raymond Aron'un asistanı olarak Sorbonne'da çalışmaya başlar. 1964 yılında Ecole des Hautes Etudes en Social Sciences'de araştırma müdürlüğü yapar. Sonra, yine aynı okulun bünyesinde yeni kurulan Avrupa Sosyoloji Merkezi'nin direktörlüğünü üstlenir. Kabiliye topluluklarında ritüel, akrabalık ve sosyal değişme ile ilgili yaptığı etnoloji çalışmalarını, "Bir Pratik Teorisi İ̧̧in Taslak" (1972) ve "Cezayir 1960" (1976) adlı eserlerle kitaplaştırır (Wacquant, 2010: 54; Bourdieu, 2013; Ritzer, 2013: 528-529).

Bourdieu sosyolojisi, kendi başına gerçekleşmiş gibi görünen bireysel eylemlerin, insanların belirli şartlarda, belirli eylemlerde bulunmasını isteyen toplumsal beklenti ile nasıl iç içe geçtiğini anlamaya çalışır. Bunu anlamak için Bourdieu, bir takım bireysel özelliklerle, toplumun istediği bazı kültürel özelliklerin bütünleşmesini göstermek için "Bir Pratik Teorisi ççin Taslak" adlı eserinde, Kabiliye kabilesi üzerine yaptığı antropolojik çalışmaların ve topluluktaki hediye alışverişinin sosyolojik çözümlemesinin neticesinde, kendi geliştirdiği habitus kavramının ana çerçevesini çizer (Elliott, 2017: 193,194).

Bourdieu'nün, savaş sonrası Batıda, kültürel sermayenin toplumsal yaşamda fırsatlara ulaşmanın temel belirleyicisi olması ve kültürel sermayenin eşitsiz dağılmasının çeşitli şekillerde sosyal hiyerarşiyi korumaya yardımcı olduğunu düşünmesi, okullaşma, sanat, entelektüeller ve siyaset sosyolojisine ilgi duymaya başlamasına neden olmuştur. O bu düşüncelerini, "Varisler: Öğrenciler ve Kültür" (1964) eseri ve "Yeniden-Üretim" (1970) adlı eserlerinde kanıtlar. İlk eserinde Fransa'daki öğrencilerin kültürel dünyalarını ve hayatlarını anketlerle inceleyerek, aileden gelen eşitsizliklerin okul tercihleri ve başarısındaki etkilerini ortaya çıkarır. Kültür sermayesi kavramı da bu eser ile ortaya çıkmıştır. Bu eserden itibaren Bourdieu, sürekli olarak sınıf farklılıklarının ne şekilde insanları etkilediğini ya da insanlara nasıl yansıdığını, detaylarıyla inceleyerek ortaya çıkarmaya çalışır. Ürettiği kavram ve kuramlar, sınıf farklııklarının sonuçları ve bu farklııkların nedenlerini anlamlandırmanın aracısıdır. 1965 yılında yayınlanan "Bir Ortalama Sanat: Fotoğrafın Toplumsal Kullanımı Üzerine Bir Deneme" isimli eserinde, fotoğrafçılığın toplumun farklı kesimleri tarafından gördüğü ilgiyi ve nasıl algılandı̆̆ını inceler. Devamında, yine sosyal sınıflar arasındaki farklılıkları ortaya koymaya yönelik, "Sanat Sevdası: Avrupa Sanat Müzeleri ve Ziyaretçi Kitlesi" (1966) isimli eseri yayınlanır (Wacquant, 2010: 55; Amman, 1995: 113-114; Jourdan \& Naulin, 2016: 9-10).

1968 yılından sonra hocası Raymond Aron'dan ayrılan Bourdieu, Eğitim ve Kültür Sosyolojisi Merkezi'ni kurar. Yapısalcı olan "Sanat Sevdası" eserinden sonra, "Sosyolog Mesleği: Epistemolojik Önceller" (1968) isimli eseri çıkar. Bu eserde Bourdieu’nün sosyoloji anlayışı bir bütünlük gösterir. 1970 yılında ise "Yeniden Üretim: Eğitim Sistemi Kuramı İçin Öğeler" isimli kitabı yayınlanır. Bu kitabında da kültür üretimi ekseninde, özellikle okul sistemi üzerinde durur. Bu eserde, okulun herkese fırsat eşitliği sağlamak yerine, sosyal sınıf farklılıklarının yeniden üretilmesine ve 
meşrulaştırılmasına nasıl katkı sağladığını gözler önüne serilir (Amman, 1995: 114; Jourdan \& Naulin, 2016: 10-11).

Bourdieu $70^{\prime} l i$ yıllarda kültür, sınıf ve güç konuları üzerine çalışır. Ecole'de eğitim vermeyi sürdürür. 1975 yılında, en ileri düzeyde toplumsal araştırmaları duyurmak ve önemli sosyal sorunları kesin bilimsel bir yaklaşım ile ele almak amacıyla, Actes de la recherche en sciences sociales isimli dergiyi kurar ve ölümüne kadar editörlüğünü yapar. Bourdieu'nün en temel yapıtlarından biri olan "Farklılıklar" 1979 yılında yayınlanır. Bu geniş hacimli eserinde üretim stratejileri kavramıyla yeni bir inceleme alanı açar. Ona göre üretim stratejileri, yemek yeme alışkanlıklarından serbest zamanın değerlendirilme şekline kadar, günlük yaşamın çok farklı yönlerini ilgilendiren bir anlam içerir. Özellikle sınıf ilişkileri, habitus ve alan kavramları üzerinden derinlemesine analiz edilir. Daha sonra habitus ve alan kavramlarının derinlemesine incelendiği "Sosyolojinin Sorunları" (1980) isimli eseri çıkar. Aynı yıl yine temel çalışmalarından biri olan ve insan eylemleri üzerine yazılmış "Pratiğin Mantığı" yayınlanır (Wacquant, 2010: 55; Amman, 1995: 114).

Bu eserlerinin yayımlanmasından sonra 1981 yılında, dünyaca ünlü College de France'da Sosyoloji Kürsüsü'ne girmeye hak kazanır. 1982 yılında dildeki değişmelerin sosyal yönleri ile tartışıldığı "Konuşmalar Demek İstiyor ki" isimli çalışması yayınlanır. Daha sonra Fransa üniversiteleri üzerine yazdığı "Homo Academicus" (1984) yayınlanır. Bu eserleri "Seçilmiş Metinler" (1987), "Martin Heidegger'in Politik Ontolojisi" (1988), "Devlet Soyluluğu" (1989), "Sanatın Kuralları" (1992) ve "Düşünümsel bir Antropoloji İçin Cevaplar" (1992) isimli yine oldukça beğeni toplayan eserleri takip eder. (Wacquant, 2010: 55; Amman, 1995: 114-115).

Bütün akademik hayatı boyunca, öğrenciler, köylüler, sanatçılar, işverenler, halk sınıfları, akademisyenler, eğitim sistemi, üniversiteler ve kültür gibi alanlar üzerine yaptığı araştırmalarla dikkatleri üzerine çekmeyi başarır. Kendi geliştirdiği alan teorisini başarılı bir şekilde literatüre kazandırır. Ayrıca, yaptığı alan araştırmaları, kendi ürettiği kavramların (alan, habitus, sermaye vb.) test edildiği araştırmalardır. Bütün bu çalışmaları, ona prestijli bir ödül getirir. Bu kapsamda, 1993 yılında Ulusal Bilimsel Araştırma Merkezi tarafından altın madalya ile ödüllendirilen ilk sosyolog olur (Bourdieu, 2013; Jourdan \& Naulin, 2016: 12).

90 'ı yıllardan sonra araştırmalarına sembolik malları da katarak sosyolojisinin ilgi alanlarını daha da genişletir. Bu ilgi alanlarına sosyal sefalet, eril tahakküm, devletin tarihsel boyutu, ekonominin siyasal oluşumu, televizyon gibi daha birçok konuyu eklemiştir. Ayrıca, ömrünün son on yılında bilim insanından angaje aydına dönüşen Bourdieu'nün, aktivist yönü ağır basar. Bu kapsamda, grevlere, işsizlere ve küreselleşme karşıtlarına destek verir. Son dönem eserlerinin bir bölümünde neoliberalizm ve küreselleşmenin çok sert eleştirisini yapmıştır. Neo-liberalizm ve küreselleşme karşıtlığı ya da eleştirisinden dolayı, 90'lı yıllarda kamusal alanda daha fazla görülür. 1995 grevlerinin ardından, Raisons d'agair adlı yayınevini bu aktivist tavrını desteklemek için kurar. Ayrıca, bir taraftan geleneksel sol anlayışı eleştirirken ve yeni toplumsal eşitsizlik türlerinin ortaya çıktığı bir dönemde, diğer taraftan Fransız ve Avrupa siyasetinde daha aktif olarak yer almaya başlar. Bu durum onun, sosyal bilimleri dengeleyici sembolik bir güç ve toplumsal adaleti sağlayacak bir alan olarak görmesiyle tutarlıdır (Wacquant, 2010: 56; Elliott, 2017: 198, Bourdieu, 2013; Jourdan \& Naulin, 2016: 12).

Bu çerçevede, 1993 yılında oldukça hacimli olan "Dünyanın Sefaleti" isimli eseri yayınlanır. Bu eserde, çağdaş sefaletin çeşitli görünümlerini tartışır. Serbest piyasa ekonomisinin ya da neo-liberalizmin etkilerinin toplumun en ücra köşesine kadar nasıl etkide bulunduğunu anlatır. Bu eser onu, toplumsal sefalet çekenlerin sözcüsü yapar. Bir yıl sonra, merkezinde eylem kuramının yer aldığı, dünyanın çeşitli ülkelerinde verdiği konferansların metinlerinden oluşan ve Türkçe'ye ilk çevrilen eseri olan "Pratik Nedenler" (1994) yayınlanır. 1996 yılında yayınlanan "Televizyon Üzerine" isimli eserinde ise, medyayı fastfood kültürüne hizmet etmek ve ciddi sosyal analiz sorumluluğunu ortadan kaldırmakla suçlamıştır. Devamında, Bourdiue'nün, sosyoloji teorisini, tarih bilgisini ve felsefi düşünceyi harmanladığı, akademisyenlere yönelik eleştirilerde bulunduğu ve simgesel şiddet, iktidar, çıkar, 
zaman, tarih, evrensellik gibi temaları yeniden ele aldığı "Akademik Aklın Eleştirisi" (1997) yayınlanır. Aynı yıl, bilimsel alanın sosyolojisinin yapıldığı "Bilimin Toplumsal Kullanımları" (1997) adlı eseri de çıkar. 1998 yılında yayınlanan "Karşı Ateşler" isimli eserinde de, bir taraftan akademik hayatın apolitikleşmesini sert bir şekilde eleştirirken, diğer taraftan da küreselleşme karşıtı hareketteki entelektüel ve sanatçıların rolüne vurgu yapar (Elliott, 2017:198). Daha sonra cinsiyete dayalı ilişkileri ve tahakkümü konu edinen "Eril Tahakküm" (1998) isimli eseri yayınlanır. Bu eserleri "Protesto Umutları" (1998), "Ekonominin Sosyal Yapıları" (2000) ve "Siyasi Alan Üzerine Söyleşi" (2000) eserleri takip eder.

2000 yılında Bourdieu'nün fikirsel ve siyasi görüşlerini içeren, "Sosyoloji Bir Dövüş Sporudur" isimli bir belgesel çekilir. Bu belgeselde Bourdieu, özellikle sosyoloğun sosyal hareketler üzerindeki etkisine vurgu yapar (Jourdan \& Naulin, 2016: 12-13).

Bourdieu bu aktivist yönüyle birlikte, akademik çalışmalarına da ara vermeksizin devam eder. Bilimin etkisi ve sosyoloji üzerine olan çalışmalarını daha da ileriye taşıyarak, akademik bir düşünce geliştirmeye çalışır. Bu kapsamda, "Bilimin Bilimi ve Düşünümsellik: College de France Dersleri 20002001" (2001), "Karşı Ataşler-2" (2001), "Bekarlar Balosu" (2002), "Bearn'da Köylü Toplumun Krizi" (2002), "Müdahaleler, 1961-2001-Sosyal Bilim ve Siyasal Eylem" (2002), "Bir Oto Analiz İçin Taslak" (2004), "Sosyolog ve Tarihçi" (2010) ve "Devlet Üzerine: College de France Dersleri 1989-1992" (2012) gibi birçok eseri yayınlanır.

Kendisinin geçmişi hakkında yazmayı ve yazıımasını istemeyen Bourdieu, ölümünden kısa bir süre önce "Bir Otoanaliz İçin Taslak" isimli eserini yazmaya başlar. Ancak, kendi sosyolojik çerçevesinin sınırlarının dışına çıkmayan Bourdieu, bunun bir otobiyografi değil, sosyolojik bir öz inceleme olduğu söyler. İnsanın kendi hayatının tek yazarı olduğu düşüncesine katılmayan Bourdieu, bu eserinde kendi hayatından kesitler olsa da, bunları onun hayatına yön veren çeşitli sosyal alanlar olarak değerlendirir. Sosyolojik bakışına uygun bir şekilde, bir taraftan hayatının toplumsal yaşamdaki alanlar tarafından şekillendirildiğini, diğer taraftan o alanlar içinde eyleyici olarak yaptıklarının bir ürünü olduğu ifade eder (Ritzer \& Stepnisky, 2013: 153).

Onun, sadece kitapları dahi dikkate alındığında ne derece üretken bir sosyolog olduğu anlaşılabilir. Arkasında geniş bir külliyat (30 dan fazla kitap, 400'e yakın makale) bırakan Bourdiue, 2002'de 72 yaşında yaşamını yitirmiştir. En çok satan kitapları "Televizyon Üzerine" ve "Dünyanın Sefaleti"dir. Ayrıca, "Varisler" ve "Ayrım" eserleri de sosyoloji klasikleri arasında yerini almıştır (Jourdan \& Naulin, 2016: 13; Sunar, 2018: 102).

\section{Bourdieu Sosyolojisinin Gelişimi ve Sosyolojiye Bakışı}

Bourdieu'nün sosyolojisini geliştirdiği sosyal ve entelektüel çerçeve, Fransız eğitim sisteminin yapısı, sosyoloji ve entelektüel hayat karşısında aldığı eleştirel tutumu anlamak açısından önemlidir. Onun sosyolojisi olağandışı bir sınıf atlama tecrübesinden doğmuş ve yararlandığı entelektüel kaynaklarının yelpazesi de oldukça geniştir. $O$, felsefe eğitimi almış, akademik hayatına bir antropolog olarak başlamış, Fransız entelektüel hayatı ile birlikte, Anglo-Amerikan ve Alman geleneklerinden de yararlanmış biri olarak, kültürel ve toplumsal açıdan Fransız entelektüel elitinden farklıdır (Swartz, 2011: 27).

Fransız sosyolojisi, Amerikan sosyolojisinden etkilenerek yeni bir evreye geçmiş ve aralarında Bourdieu'nün de yer aldığı birçok sosyolog, istatistik yöntemlerden faydalanarak saha çalışmaları yapmaya başlamıştır. Bundan dolayı, onun sosyolojisinin en temel özelliği istatistiki yöntem ve anket tekniğinden yararlanmasıdır. Bütün çalışmalarında ön plana çıkan bu özelliği, 1979 yııında yayınlanan ve en önemli çalışmalarından biri olan "La Distinction" adlı eserinde de çok net bir şekilde görülmektedir. 2015 yılında "Ayrım" ismiyle Türkçeye çevrilen eser, anket tekniği ile yapılmış ve günlük hayata yansıyan birçok farklılığı içeren çok fazla istatistiki veri içermektedir. Bourdieu, istatistiki yöntemlere eğilirken, Fransız sosyolojisinin teorik geleneğinden kopmamış, aksine bu 
istatistiki bilgilerden hareketle, derinlemesine analizler yapmayı ve kendine ait yeni kavramlar geliştirmeyi başarmıştır (Amman, 1995: 112-113).

O, ilk çalışmalarından hareketle, Durkheim'e yakın olduğu izlenimi verse de, bunun ancak metodolojik açıdan bakıldığında mümkün olduğu söylenebilir. Gerek temel iddiaları, gerek kavramları ve üzerinde durduğu konular açısından çatışma kuramına daha yakın olduğu ve sınıf farklılıkları üzerine yaptığı değerlendirmelerden dolayı da, Marksist bir çizgide yer aldığı görülmektedir. Ancak, Bourdieu sosyolojisinin içerik bakımından temel yerinin strüktüralist (yapısalcı) ekol içinde olduğu söylenebilir (Amman, 1995: 112-113).

Üretken bir sosyolog olarak, sürekli olarak yeni kavramlar geliştirmiş, her zaman daha önce ürettiğinin üzerine yeni şeyler koyarak, hem temel iddialarını güçlendirmiş hem de sosyolojisini ya da ekolünü daha da zenginleştirmiştir. Birçok eserinde, ortaya attığı teoriler ve kavramlar üzerinden, toplumdaki hiyerarşik yapıları, hegemonik yapıların nasıl yeniden üretildiğini ve bu yapılara karşı yapılan mücadeleleri, özellikle sınıf farklılıklarının toplumsal yaşamda nasıl ortaya çıktığını ya da görünür olduğu anlamaya çalışır. Bir diğer ifadeyle, toplumsal sınıfların varlığını ve devamlıı̆ı̆ını, zengin istatistiki yöntemlerle birlikte göstermeye çalışır.

Sosyoloji, toplumsal hayatta çok açık olarak görünen ya da görünmeyen meseleleri açığa çıkarmak için uğraşır. Özellikle sosyolojinin, toplumsal yaşamda gizli kalmış meseleleri gün yüzüne çıkarması, ona göre, örtülü iktidar ilişkilerinin de ortaya çıkması anlamına gelir (Amman, 1995: 115). Bourdieu, sosyolojinin tarafsı bir bilim olabileceğini düşünmemekte ve sosyolojinin ilk etapta toplumdaki iktidar ilişkilerini anlayarak, sosyal yapıyı çözümlemeye başlaması gerektiğini iddia etmektedir (Bourdieu, 2016: 23-43).

Onun sosyolojisinin öne çıkan özelliklerinden biri de, Marx, Durkheim ve Weber gibi klasik sosyologların, temelde zıt olan görüşlerini bir araya getirme çabasıdır. Bourdieu, toplumsal olgu ve olayları, bireyi dışlayarak inceleyen objektivist yaklaşımlarla, bireyin kendi eylemlerine verdiği anlamlar üzerinden inceleyen sübjektivist yaklaşımları birleştirmeye çalışmaktadır. Yaptığı araştırmalarda, istatistik yöntemlerle birlikte, daha çok Weber'in metodolojisini benimsediği görülür (Amman, 1995: 119-120). Bu sentezin sonucunda da, yapısalcı yapımcılık (inşacılık) ismini verdiği kendi sosyolojik teorisini geliştirmiştir (Arslantürk \& Amman, 2012: 505).

Araştırılan olguların tarihsel geçmişlerinin tüm ayrıntıları ile ortaya çıkarılması, teorik ve tarihsel arka planın bir bütün olarak değerlendirilmesi ve kuramın uygulamada karşılığının olması gerektiğini ileri süren Bourdieu, uygulaması olmayan kuramın doğrulanamayacağını iddia eder (Görgün Baran \& Öksüz, 2011: 3). O, teori ve pratiği bir bütün olarak düşünür ve bu bütünlük çerçevesinde bir kurama ulaşmaya çalışır.

Bourdieu, salt yapı ya da bireyi göz önünde bulunduran, dolayısıyla, ikisinden birini göz ardı eden her türlü görüşten uzak durur. Bir diğer ifadeyle, hem yapıyı hem de bireyi göz önünde bulunduran veya yapı-birey gibi ikiliklerden uzak duran, kendisinin inşacı yapısalcılık ya da yapısalcı inşacılık olarak isimlendirdiği bir metodolojik yaklaşım önerisinde bulunur (Görgün Baran \& Öksüz, 2011: 15-17). Ona göre bu yaklaşım, birçok olay ve olgunun açıkça görülmesine imkan sağlayacaktır.

Sosyolojide önemli bir etkisi bulunan yapısalcılığın, çok farklı disiplinlerin ilgi alanına girmesi ve farklı değerlendirme biçimlerinin ortaya çıkmasından dolayı, tanımlanması zordur. Yapısalcılığı lingiustik'ten, antropoloji'ye taşıyan Levi-Strauss, onun bilimsel bir yöntem olduğunu söylemektedir (Elliott, 2017: 104). Yapısalcı̆ı̀n en temel özelliği, bir olay ya da olguyu açıklarken yapıya daha fazla vurgu yapmasıdır. Bourdieu yapısalcılı̆ı ise, daha önceki kullanımlarından farklı olarak, toplumsal hayatta bireylerin davranışlarını belirleyen objektif yapıların olduğunu ve bu süreçte toplumsal yapı ile birlikte, ona bağlı simgesel bir yapının ya da habitusun varlığını vurgulayarak, klasik yapısalcılığın sınırlarını aşmıştır (Amman, 1995: 122-123).

Bourdieu sosyolojisinde düşünümsellik önemli bir kavramdır. Düşünümsellik araştırılan olgularla ilgili her türlü detayı, sürekli geri dönüşler yaparak değerlendirmek anlamına gelir. Her aşamanın tekrar 
tekrar gözden geçirilmesi, araştırılan konunun daha sağlıklı olması için araştırmacıya önemli bir avantaj sağlayacaktır. Onun düşünümsel sosyolojisinin temelinde, araştırmacının kendisini de araştırılan olgunun bir parçası olarak değerlendirmesi önerilir. Dolayısıyla, bu yöntem araştırmacıya da araştırılan olgu karşısında kendisinin nasıl konumlanacağını göstererek, hem araştırmanın hem de araştırmacının daha nesnel olmasına katkı sağlamaktadır (Görgün Baran \& Öksüz, 2011: 4-5, 17). Ayrıca, Bourdieu düşünümselliği araştırmacıya, bireysel olandaki toplumsal olanı veya özel olandaki geneli görme imkanı verir (Bourdieu \& Wacquant, 2014: 40).

Bourdieu'nün analizlerinde kullandığı kavramlardan biri de semboller ya da simgelerdir. Sembolik alan, sembolik şiddet ve sembolik sermaye kavramlarını sıklıkla kullanır. Onun sosyolojisi, toplumsal yapılar ile sembolik yapıları analiz etmek ve bu iki yapı arasındaki görünmeyen ilişkileri görünür hale getirmek amacı taşır. Bu kavram temelde, yorumsamacı yaklaşımın sembolik toplum anlayışına dayanır. Bu anlayışta değer ve anlam önceliklidir (Amman, 1995: 129).

Toplumsal yaşamı anlamanın ya da anlamlandırmanın bir vasıtası olan semboller, Bourdieu açısından, temelinde iktisadi farklıklar olan hükmedenler ile hükmedilenler şeklindeki klasik Marksist analizi, daha farklı yönleriyle ele alma imkanı verir. $\mathrm{O}$, asıl mücadelenin ya da çatışmanın sembolik alanda yaşandığını ve bu mücadelenin tahakkümü meşrulaştırdığını ifade etmektedir (Ansart'tan aktaran Amman, 1995: 129-130).

\section{Bourdieu Sosyolojisinin Temel Kavramları}

Bourdieu sosyolojisinin en temel özelliklerinden biri, kendine özgü kavramlar ya da kuramlar geliştirmiş olmasıdır. $O$, bütün düşünce, fikir ya da görüşlerini bu kavramlar üzerinde açıklamaya çalışmıştır. Birçok araştırmanın, onun geliştirdiği kavramlar üzerinden anlamlandırılması ve kavramlarının birçok sosyolog tarafından kullanılması, onun sosyolojisinin başarısını gösterir. Bourdieu'nün geliştirdiği kavram ya da kuramların başında habitus teorisi gelir. Alan ve sermaye kavramları da oldukça önemlidir. Ayrıca, bu geliştirdiği kavramlar üzerinden sınıf, beğeni ve beden üzerine yaptığı analizler de çok değerlidir.

Bourdieu, temel kavramlarının daha anlaşılır hale gelmesi için metaforlara başvurur. Kullandığı metaforlardan biri de oyundur. Bourdieu'de alan oyunun oynandığı yerdir ve her bir alanın kendine özgü oyun kuralları (doxa) vardır. Bu oyun kuralları aynı zamanda, alan için gereken sermayenin elde edilme ya da tutulma kriterlerini de belirler. Ona göre, alanın en temel özelliği kolektif katılımdır. Ancak, oyuncuların oyuna girmesi için, oyundan belirli kazanımlarının ya da menfaatlerinin olması gerekir. Bir diğer ifadeyle, oyuncuların oyuna inanması ve oyundan elde edecekleriyle, bu oyunu oynamaya değer bulması gerekir. Bourdieu, oyundan elde edilecek menfaatleri illusio kavramı ile açıklar ve oyuna katılmak, onu oynanmaya değer bulmakla eşdeğerdir. Dolayısıyla, oyuna dahil olmak alandaki mevcut kuralları da kabul etmek anlamına gelmektedir. (Bourdieu, 1999: 405; Jourdan \& Naulin, 2016: 123). Alandaki her bir oyuncunun, oyun esnasında kullanabileceği belirli kartları vardır. Bu kartları, Bourdieu'de sermaye kavramı karşılar. İlk etapta iktisadi, kültürel ve sosyal sermaye olarak ortaya çıkarlar ve her birinin şartlara göre ayrı ayrı önemi vardır. Bu sermayelerin bir araya gelmesiyle birlikte, dördüncü sermaye türü olan simgesel sermaye ortaya çıkar. Bütün bu sermaye türleri, oyuncuların elindeki farklı kartlardır ve her kartın işlevi oyundan oyuna değişir. Bir diğer ifadeyle farklı sermayeler, farklı alanlarda işlevsel olabilir (Görgün Baran \& Öksüz, 2011: 6).

\section{Alan}

Bourdieu, toplumsal yapıdaki birbiri ile doğrudan ilişkili olan toplumsal bağlantılar bütününü alan terimi ile açıklar. Ona göre toplumsal alan, toplumdaki bütün ilişkileri içine alan bir sisteme atıf yapar. Toplumdaki her alan, kendine özel kuralları olan bir sistemdir. Bir diğer ifadeyle alan, kendi kurallarını belirleyen ve alana girmek isteyenlere de bu kuralları dikte eden bir güçtür. Güç veya çıkar ilişkileri, bu sistemin temel öğesidir (Amman, 1995: 126). 
Bourdieu alanı tanımlarken yine Weber'e başvurur. Toplumsal hayatın salt ekonomiye indirgenerek açıklanamayacağını, toplumdaki hiyerarşik yapıların oluşumu ve hegemonik yapıların yeniden üretimini anlayabilmek için, eğitim, kültür, din, siyaset gibi daha birçok alanı dikkate almak gerektiğini ifade eder. Marksist yaklaşımın toplum analizinde kullandığı ekonomik alt yapıdaki üretim ilişkileri ya da sınıf kavramı yerine, Bourdieu alan kavramını kullanır. Alan, içinde çeşitli sermaye türlerine sahip konumların yer aldığı ve insanların bu farklı konumları elde etmek için sürekli çabaladıkları bir mücadele alanıdır (Görgün Baran \& Öksüz, 2011: 7). Bir diğer ifadeyle alan, rekabetin çok yoğun olarak yaşandığı, alanda yer alan bütün insanların kendini ispatlama gayreti içinde olduğu mekan ya da konumlardır (Dever, 2017: 223).

Bourdieu'ye göre, bir alanın analizinde, alanın iktidar ile ilişkisi ve ona göre konumunun çözümlenmesi, rekabet halindeki bireyler veya kurumlar arasındaki bağlantıların nesnel yapısı ve bireylerin habitusları önemlidir (Bourdieu \& Wacquant, 2014: 90).

Alan ve habitus arasındaki ilişkide, alan varlığını devam ettirmek için habitusu şekillendirir. Alanın yeniden üretilmesi için, bireylere ihtiyaç vardır ve bu bireyler ancak habitus vasıtasıyla alanı yeniden üretirler. Dolayısıyla, alanın varlığı habitusun yeniden üretiminin sağlanmasına bağlıdır (Görgün Baran \& Öksüz, 2011: 11). Pierre Bourdieu (2010: 48), habitus ve alan arasında karşıılıklı bir ilişki olduğunu ifade etmektedir. Ona göre, alan habitusu yapılandırırken, habitus da alana ilişkin algıyı yapılandırır.

\section{Habitus}

Habitus kavramı Bourdieu'den önce, Durkheim, Mauss, Weber ve Veblen gibi teorisyenler tarafından kullanılmıştır. Ancak, bu teorisyenlerden hiçbirinde habitus kavramı, Bourdieu'de olduğu gibi belirleyici değildir. Habitus, daha sonra fenomenolojide Husserl tarafından geçmiş deneyimler ile gelecek eylemler arasında bir köprü olarak kullanılmıştır. Sonra Schutz, Merleau-Ponty ve Elias gibi düşünürler tarafından da farklı anlamlarda kullanıldığı görülmektedir. Bourdieu, habitus kavramını yukarıda değinilen teorisyenlerden farklı bir anlamda, eyleyicileri içeriden yönlendiren yapılaştırıcı bir sistem olarak tanımlar (Tatlıcan \& Çeğin, 2010: 315). Habitus teorisi, onun tarafından geliştirilen bir teoridir. Bu teori, sosyal hayattaki tahakküm ilişkilerini açıklamaya çalışır ve bu yönüyle yapısal çatışmacı bir teori olarak değerlendirilir (Amman, 2000: 139).

Habitus, tıp literatüründe bedenin dışarıya yansıyan tutumu ve davranış biçimidir. Bourdieu tarafından sosyolojiye aktarılan habitus, insanların toplumsal geçmişinden ve sahip oldukları statülerinden kaynaklanan oluş biçimlerini ifade eden bir kavramdır (Coiffier'den aktaran Amman, 2000: 139). Habitus, Bourdieu tarafından, sosyal yapı ile sosyal eylem arasındaki bağı oluşturan, bir takım edinilmiş düşünce, davranış ve beğeni kalıpları için kullanıımıştır (Marshall, 2005: 291). Ayrıca o, habitus kavramını, birey tarafından benimsenen ve kalıcı bir şekilde bireyin benliğinin ayrılmaz bir parçası olan şeyler olarak tanımlamış ve bu yönüyle alışkanlık kavramı ile karıştııımasını önlemeye çalışmıştır. Habitus bireylerin geçmiş yaşamlarıyla ilgili olan, üretici ve aynı zamanda değişimin de bir aracıdır (Amman, 1995: 125).

Habitus, bir taraftan bireyi şekillendiren diğer taraftan bireyin eylemleri tarafından şekillendirilen bir yapıdır. Eylemlerin tekrarı habitusun yeniden üretilmesine neden olur. Habitus, bilinçli bir eylem olmanın ötesinde, insanların toplumsal alanda kendine yer edinmek için yaptığı davranışlardır. Habitus içinde yaşadığımız toplumsal hayatın sınırlarını öğretir ve karşılaşılan çeşitli sorunlarda bireye çıkış yolları sunar (Görgün Baran \& Öksüz, 2011: 9-11). Bir diğer ifadeyle habitus, üzerinde çok düşünmeden gerçekleştirilen, büyük oranda sosyalleşme sürecinde edinilen, bireylerin kimliklerini ve toplumsal yaşamdaki konumlarını belirleyen ve bireylerin davranışlarını toplumun beklentilerine göre şekillendiren eğilimlerin tamamıdır (Calhoun, 2010: 103).

Geçmişten geleceğe uzanan bir yapı olarak habitusun tarihsel bir boyutu da bulunmaktadır. Bu durum bireysel ya da kolektif eylemlerin, tarihsel bir süreç içinde üretildiğini göstermektedir (Elliott, 2017: 195). Bundan dolayı habitus, geçmiş tecrübeler ile şimdinin eylemlerinin bir ürünüdür ve bireylerin ait olduğu sosyal sınıfının da önemli bir belirleyicisidir (Görgün Baran \& Öksüz, 2011: 10). 
Bourdieu, sosyal sınıflar üzerinde yaptığı analizler ile yeni perspektifler geliştirmiş ve bu yönüyle de çatışma teorisyenleri arasında önemli bir yere sahiptir. 0 , hükmedenler ve hükmedilenler şeklinde marksist analizi kabul etmekle birlikte, onlardan farklı olarak, sınıflar arasındaki mücadeleyi salt iktisadi alanla sınırlandırmamış, din, sanat, siyaset gibi daha birçok sembolik alanı da içine alacak şekilde sınıfları değerlendirmiştir. Ayrıca, Weber'in meşruiyet kavramı üzerinden de bu konuyu ele aldığı görülmektedir. Buna göre, bir toplumda toplumsal bütünleşme varsa, hükmeden sınıflar tahakkümünü çeşitli araçlarla meşrulaştırmaktadır. Bu meşrulaştırma, tüm sembolik alanlarda kendini göstermektedir (Amman, 1995: 130).

Bourdieu, Marksist anlayışın ekonomik indirgemeciliğini Weberci kültürel alanın özgünlüğü düşüncesiyle ve Durkheim'ın sınıflandırma çalışmalarıyla sentezleyerek, kendine özgü bir sınıf teorisi geliştirmeye çalışır (Wacquant, 2010: 65).

Bourdieu, sınıf analizinde ya da tanımında sınıf habitusu kavramından bahsetmektedir. Ona göre sınıflar arasındaki temel farklılıklar sınıf habitusundan kaynaklanmaktadır. Bütün yaşam tarzı farklılıkları sınıf habitusunun bir sonucudur. İnsanların en temel ihtiyaçlarından, daha yüksek düzeydeki kültürel pratiklerine kadar, toplumsal yaşamın hemen her alanında ortaya çıkan farklıııklar, "Ayrım" kitabı başta olmak üzere birçok eserinde çok net bir şekilde görülmektedir. Ayrıca, müzik, spor, estetik ve etik gibi birçok alanda ortaya çıkan bu farklılıklar yeniden üretilmektedir (Amman, 1995: 131).

Bir diğer nokta, Bourdieu'nün iktisadi, kültürel, sosyal ve simgesel sermaye türlerinin toplumsal hayatta var olması ve insanlar arasındaki dağııımı da, sınıfların belirlenmesinde önemlidir (Ünal, 2018: 74). Bu sermaye türlerinin, toplumda farklı şekillerde ya da eşitsiz dağılması, sınıflar arasındaki farklılıkların devamı anlamına gelmektedir.

Günümüzde özellikle hakim sınıf tarafından, farklııklar yeniden üretilmektedir. Sınıflar arasındaki sınırların belirsizleşmesi, hakim sınıfın tahakkümünün çok farklı alanları etkisi altına almasıyla ilişkilidir. Dolayısıyla, sınıf öldü ya da sınıfın sonu iddialarının aksine, farklıııkların artarak devam ettiği görülmektedir.

\section{Sermaye}

Bourdieu'ye ait önemli kavramlardan biri de sermayedir. Iktisadi bir anlam ihtiva eden sermaye kavramı Bourdieu tarafından daha da genişletilerek, salt bir ekonomik anlam içermekten çıkarılmış ve daha farklı anlamlar yüklenmiştir. Bu kapsamda o, iktisadi sermaye yanında, sosyal, kültürel ve simgesel sermaye türlerinden de bahsetmektedir.

Bourdieu'de sermaye hem bireylerin pratiklerinde başvurdukları kaynaklar, hem de bireylerin diğer bireyleri tahakküm altına almak için kullandıkları hegemonik ilişkiler anlamına gelmektedir (Göker, 2010: 280). Bourdieu'de sermaye, aynı zamanda toplumsal alanın da önemli bir belirleyicisidir.

iktisadi sermaye, uzun bir süre sınıfları birbirinden ayırmak içi kullanılan en temel faktördür. Marksist anlamda iktisadi sermaye, üretim araçlarına sahip olan burjuva sınıfını nitelemek için kullanılırken, Bourdieu'de insanların sahip olduğu servet, gelir ya da mülk için kullanılır (Görgün Baran \& Öksüz, 2011: 12). Günümüze gelindiğinde ise, salt iktisadi sermaye üzerinden sınıf analiz yapmanın yeterli olmadığı görülmektedir. Ona göre, sağlıklı bir sınıf analizi için, diğer sermaye türlerini de hesaba katmak gerekmektedir (Amman, 1995: 127). İktisadi sermaye, doğrudan ya da dolaylı olarak para ile ilgili ya da paraya dönüşebilen servet, gelir ya da mülk sahipliği gibi, sadece iktisadi kaynaklara sahip olmayla ilgilidir. Ancak, Bourdieu'de sermaye, sadece iktisadi olan ile sınırlandırılmaz ve bu sermaye iktisadi olmayan, başta kültürel sermaye olmak üzere, diğer unsurlarla da ilişkilendirilir. Hatta o, iktisadi sermayenin, kültürel sermaye ile birlikte tahakkümün aracı olduğunu ve eşitsizliği yeniden ürettiğini belirtmektedir (Göker, 2010: 282-283).

Kültürel sermaye, genel olarak eğitim yoluyla elde edilen bir sermayedir. Bourdieu ise kültürel sermayenin iki yolla elde edildiğini ifade etmektedir. Illki formel eğitim (okul) yoluyla kazanılan, ikincisi 
ise, aile içinde doğal olarak edinilen ya da aileden miras kalan bir sermayedir (Amman, 1995: 127). Özellikle aileler sosyalleșme sürecinde kendi ebeveynlerinden öğrendiklerini, sosyalleştirme sürecinde çocuklarına aktarır ve çocuklarının da aynı süreçlerden geçmelerini sağlarlar. Böylece, kültürel sermayelerini nesilden nesle ulaştırarak, yeniden üretilmesini de sağlamış olurlar (Görgün Baran \& Öksüz, 2011: 12). Kültürel sermaye kavramı Bourdieu tarafından, "Varisler: Öğrenciler ve Kültür" (2014) adlı eserinde Fransa'daki öğrencilerin kültürel yaşamlarının incelenmesinin ve ailelerinden gelen eşitsizliklerin ya da kültürel mirasın farklı olmasının, öğrencilerin okul tercihleri ve başarısını etkilediğinin bulunmasıyla, ortaya atılır. Dolayısıyla, kültürel sermayenin alt tabakadan üst tabakaya doğru artması ya da toplumda eşitsiz dağılması sonucunda, eşitsizlik daha okul sıralarından başlayarak, bütün toplumsal yapıda kendini gösterir. Onun sosyolojisinde, diğer sermaye türlerine göre daha merkezi bir öneme sahip olan kültürel sermaye, toplumsal yapıda dini, politik, bürokratik ve eğitimsel sermaye gibi farklı şekillere bürünebilmektedir (Göker, 2010: 282). Ona göre (Aktaran Göker, 2010: 282-283) kültürel sermaye üç şekilde ortaya çıkar. İlki, ailenin sosyal statüsüne göre öğrenilen dil pratikleri, yazma şekli ve bedenin farklı şekillerde kullanılması ve kendisini en yoğun olarak, eşitsiz bir yapı üretecek şekilde eğitim alanında gösteren bedenselleşmiş halidir. İkincisi, kitaplar, resimler, sanat ve bilim eserleri gibi kültürel hünerler gerektiren nesneler üzerinden, nesneleşmiş halde ortaya çıkar. Üçüncüsü ise, eğitim ve bürokrasi aracılığıyla insanların eşitsiz olarak toplumdaki statülere yerleştirmesiyle ortaya çıkan kurumsallaşmış halidir.

Kültürel sermayesi yüksek olan ebeveynler düşük olanlara kıyasla, çocuklarının eğitimine daha fazla önem vermekte ve ciddi bir yatırım yapmaktadırlar. Dolayısıyla, ailenin farkındalığı ve okul eğitimi ile elde edilen kültürel sermaye aracılığıyla, eşitsizliğin yeniden üretildiği görülmektedir (Bourdieu, 2006: 36-37).

Sosyal sermaye ise, bireyin sahip olduğu sosyal çevrede, kurduğu sosyal ilişkiler neticesinde edindiği sermaye türüdür (Amman, 1995: 127). Insanların diğer insanlarla olan ilişkileri, herhangi bir gruba olan üyelikleri, kurduğu ilişkilerin ona getirdiği sorumlulukları ve ayrıcalıkları, sosyal sermayenin oluşumunda önemli bir etkiye sahiptir (Göker, 2010: 283). Bir diğer ifadeyle sosyal sermaye, insanların grup üyelikleri ya da bu üyelikler vasıtasıyla oluşturduğu ilişki ağlarıdır (Çelik, 2014: 268). Bourdieu sermayeyi, insanların birtakım toplumsal alanlara ya da sosyal ortamlara girerek ve bu alanlarda elde ettiği kazanımlar olarak tanımlar (Bourdieu'den aktaran, Wacquant, 2010: 62). Sosyal sermayenin fazla olmasında bireyin hem kurduğu ilişkilerin hem de ilişki kurduğu insanların sayısı önemlidir. Ayrıca, sosyal ilişkilerin belli bir toplumsal yapı içerisinde gerçekleşmesi, toplumsal yapının da sosyal sermaye ediminde etkili olduğunu göstermektedir. Sosyal sermaye, ekonomik ve kültürel sermayeye kıyasla, alanın temel pratiklerini açıklamada daha ikincil konumdadır.

Onun üzerinde durduğu diğer bir sermaye türü ise simgesel (sembolik) sermayedir. Simgesel sermaye, iktisadi, kültürel ve sosyal sermayelerin bir araya gelmesi ile oluşur. İnsanların sahip olduğu, fiziksel görünüm, diplomalar, yaşadığı mekan, kullandığı arabalar, yaptığı sporlar, kıyafetler, madalyalar vb. araç-gereçlerin hepsinin simgesel bir anlamı vardır. Bunlar gibi gösterge değeri olan eylemlerin hemen hepsi, bilinçli bir şekilde yapılır ve temelinde başkaları tarafından kabul ya da saygı görme vardır (Görgün Baran \& Öksüz, 2011: 12; Bourdieu, 2006: 149). Bourdieu sosyolojisinde simgesel sermaye, din, sanat, bürokrasi ve eğitim gibi çeşitli mücadele alanlarında, hegemonik ilişkilerin simgesel göstergeler üzerinden nasıl meşrulaştırıldığını ya da normalleştirildiğini göstermek için kullanılır (Göker, 2010: 284). Simgesel sermaye, bedenden dile, kıyafetten arabaya kadar insanlara sağladığı fayda ve onları diğer insanlardan farklılaştıracak algılar ve beğeni kalıplarıdır.

$\mathrm{O}$, sermaye kavramını salt iktisadi bir kavram olmaktan çıkararak, ona yeni anlamlar yüklemesinin yanında, kavram üzerinden önemli sosyolojik analizlere girişmiştir. Buna göre Bourdiue, bu sermaye türlerinin sosyal sınıflar üzerinde farklı şekillerde bulunduğunu ifade etmektedir. Egemen sınıf içinde yer alan büyük tüccar ve sanayicilerin iktisadi sermayesi fazla, kültürel sermayesi ise görece düşüktür. Bilim insanları ve sanatçılarda ise, kültürel sermaye yüksek, iktisadi sermaye ise düşüktür. Orta sınıflara ait çeşitli meslek gruplarında ise, iktisadi ve kültürel sermayenin eşit bir şekilde dağıldığını 
ifade etmektedir. Alt sınıflarda ise, iktisadi sermayenin hiç olmadığı ve kültürel sermayenin ise, çok az olduğu görülmektedir (Bourdieu, 2015a: 177-195).

Bourdieu, çatışmayı toplumsal yaşamın temeli olarak değerlendirir. Ona göre, bütün sosyal düzenlemelerin odağında iktidar mücadelesi vardır. Günümüz kapitalist toplumlarında asıl mücadele iktisadi sermaye ile kültürel sermaye arasında yaşanmaktadır. İktisadi ya da kültürel sermaye arasındaki bu mücadele, aynı zamanda, iktidar alanında yaşanan mücadelenin de temel belirleyicisi olmaktadır. Bu mücadelenin, iktisadi sermayesi daha fazla olanların lehinde olduğu görülmektedir (Corcuff, 2010: 417; Calhoun, 2010: 113).

Burada önemli olan nokta, ister iktisadi ister kültürel sermaye olsun, sahip olunan sermaye oranı fazla ise, bunun her zaman kişilere önemli avantajlar sağladığıdır. Ayrıca, sermaye kavramı günümüz toplumlarını -sınıf yapılarını- değerlendirebilmek için de önemli fırsatlar verir. Günümüzde sınıflar arasındaki sınırların grileşmesi, daha önceki sınıf analizlerinin günümüz sınıflarını anlamada yetersiz kalmasına neden olmuştur. Bundan dolayı, onun alan, sermaye ve habitus kavramları günümüzün iç içe geçmiş sınıf yapılarını anlamak açısından önemlidir (Görgün Baran \& Öksüz, 2011: 14-15).

\section{Spor Sosyolojisine Katkıları}

Bourdieu'nün en önemli özelliği geliştirdiği kavram ya da kuramları pratiğe aktarmasıdır. 0 , teorik açıdan mükemmel fakat uygulaması olmayan bir kuram geliştirmeyi istememektedir. Dolayısıyla, kavram ve kuramlarını toplumsal yaşamdaki pratikler üzerinden analiz etmiştir. Onun ürettiği teori ya da kavramları test ettiği pratiklerden biri de spordur. Alan, habitus, sermaye gibi bütün kavram ve kuramlarının spor üzerinden analizini yapmak mümkündür.

Aşağıda alan, sermaye, habitus, beden ve beğeni başılıkları altında detayları ile analiz edilen sportif pratiklere dair, Bourdieu (2015a: 318) tarafından yapılan ampirik araştırmanın bazı sonuçları şu şekildedir. Üst düzey yöneticiler ve serbest meslek sahipleri, okul müfredatlarının çocuklarının fiziksel gelişimine yeterince zaman ayırmadığını düşünmekte, düzenli olarak bir ya da birden fazla spor yapmakta ve tenis, binicilik, kayak, yüzme, jimnastik ve atletizm branşları ile ilgilenirken, işçiler ise, spor müsabakalarını televizyondan takip etmekte, çocuklarının şampiyon bir sporcu olmasını istemekte ve futbol branşı ile ilgilenmektedirler.

Bu meslekler aynı zamanda farklı bir habitus ve sermaye hacmi anlamına gelmektedir. Dolayısıyla, spor alanında ortaya çıkan bu farklı eğilimler, bireylerin sahip oldukları farklı habitusun ve sermayenin bir yansımasıdır.

Hem dünyada hem de Türkiye'de Bourdieu'nün kavramlarını kullanarak, spor üzerinde analizler yapan birçok sosyolog bulunmaktadır. Dünyada (Wacquant, 2012; Timbur'dan aktaran Evren, 2018: 252-253) ve Türkiye'de yapılan bazı çalışmalarda (Yüksel, 2012; Yüksel, 2018; Kaplan \& Akkaya 2013; Yılmaz Anatca \& Yılmaz, 2019), onun Fransa'da yaptığı araştırma sonuçlarıyla kimi yönleriyle farklııklar olsa da, genel olarak benzer sonuçlar çıktığı görülmektedir.

\section{Alan}

Bourdieu alan kavramı ile bireylerin yapılaşmış bir mekanda yer aldığını ifade eder. Ona göre, her alan (eğitim, iktisat vb.) farklı bir sosyal içeriğe sahiptir. Alan, bireylerin varlığından bağımsız olarak, daha öncesinde vardır (Elliott, 2017: 196). Dolayısıyla spor alanı da, her yeni başlayanın hazır olarak bulduğu, kurallara, tekniklere, sembollere, malzemelere ve kendine özgü değerler sistemine sahiptir (Bourdieu, 2015a: 307). Bir diğer ifadeyle, sportif pratiklerin ayrımı ve bu pratiklerin sosyal sınıflar için anlamı, spor alanında yer alan ya da alana yeni girenin müdahale edemeyeceği, spor alanında yer alan kurum ve eyleyicilerin kendi aralarında yaşadığı rekabet ve mücadelenin tarihi sonucunda şekillenmiştir (Bourdieu, 2015b: 110).

Bourdieu, her bir alanın kendine özgü bir tarihinin olduğunu ve alanın detaylı bir analizi için bu tarihsel sürecin incelenmesi gerektiğini ifade eder (Featherstone, 2005: 148). Alan üzerinde yaşanan bu değişimi spor alanında da takip etmek mümkündür. Örneğin, İngiltere'de önceleri halk 
kesimlerinin oynadığı sporlar, XIX. yüzyılda elitlerin çocuklarının okuduğu okullarda, elitlere ait ahlak ve değerler ile bezenerek, önemli oranda anlam ve işlev değişikliği yaşamış ve elitlerin sporu haline gelmiştir. Ancak aynı sporlar, zaman içerisinde halk kitlelerinin yoğun talebi sonucunda tekrar kitlelerin yaptığı bir spora dönüşmüştür (Bourdieu, 2015a: 307).

Halk kitlelerinin oynadığı geleneksel oyunlardan spora doğru olan dönüşümü-en azından Batı içinElias (2008) tarihsel kırılma, Bourdieu (2016: 207) ise adım adım gerçekleşen bir kopuş olarak nitelendirmektedir. Bu çerçevede Elias, modern spor ile modern öncesi dönemdeki sportif faaliyetleri birbirinden ayırırken, Bourdieu ise modern öncesi sporlara haksız bir şekilde geleneksel oyunlar muamelesi yapıldığını ileri sürmektedir. Bourdieu gibi bazı teorisyenler Elias'ın aksine, Avrupa'da modern sporların geleneksel halk oyunların dönüşümü ile ortaya çıktığını kabul etmektedirler (Coakley, 1998: 67). Ayrıca Bourdieu (2015b: 97) sporun tarihinin, görece olarak bağımsız bir tarih olduğunu, tarihteki büyük ekonomik ve sosyal dönüşümlerden etkilense de, kendi temposuna, kendi gelişim yasalarına ya da kendi krizlerine sahip olan özgül bir kronolojisi olduğunu söyler. Ancak modern spor, artık yalnızca bedensel bir faaliyet değildir, özellikle kendisini daha önce yapılan oyun benzeri faaliyetlerden ayıran karmaşık sosyal bir olguya dönüşmüştür (Taarruz, 2013: 145). Dolayısıyla spor alanı, günümüzde birçok ilişkinin var olduğu kozmopolit bir alandır.

Günümüzde sportif pratikler, katılımcılarına sadece sağlık, form ve güzellik gibi katkılar sunmanın ötesinde, farklı sınıfların dağılımında önemli bir belirleyici olarak, onlara çeşitli sosyal getirileri olan bir alandır (Giulianotti, 2005: 162).

Bir taraftan elit tabakanın sınırlarının zorlanması, diğer taraftan bu sınırlardan çok az kişinin geçebilmesi, elit tabakanın itibarını korumasının temel mantığının göstergesidir. Bir alanın itibarı, dışarıda bıraktıklarına ve kabul ettiklerinin kalitesine bağlıdır. Dolayısıyla, bu durum alanın kalitesini de belirleyen temel bir husustur. Her türlü katıldığımız pratiklerin sınıflandırıcı olduğu bu dünyada, görünmek gereken yerlerden (şık kulüpler ya da restoranlar) katıldığımız faaliyetlere (golf, bale gösterisi) kadar, her bir eylem bulunduğumuz alana dair bilgi verir (Bourdieu, 2014: 197). Bundan dolayı, insanların içinde bulunduğu spor alanı (yelken ya da golf kulübü) ya da katıldığı sportif pratik de (kayak, binicilik), bulundukları alanın sınırları çerçevesinde belirlenir. Çünkü, herkesin sınıflandır(ı)ma kriterleri birbirinden farklıdır.

Bir sportif pratiğin meşru biçimleri ya da yapılabilmesinin şartları noktasında -para, zaman, malzeme, mekan vb.- yaşanan çatışmalar, çoğunlukla, alanın kendi işleyişindeki toplumsal farklııkları yansıtır (Bourdieu, 2015a: 309). Örneğin kitle sporunun olmazsa olmaz üç ön koşulu, zaman, para ve mekandır. Yeterli paraya ya da kaynağa sahip olup, zamanı kalmayan, hem paraya hem de zamana sahip olup da uygun ortam bulamayanlar için kitle sporu söz konusu değildir (Amman, 2006: 15). Bu üç unsura, aynı anda sahip olmayanların sportif alanda yer almaları mümkün değildir.

\section{Habitus}

Bourdieu'ye göre habitus, bireylerin yaşadıkları sosyal dünyada karşılaştıkları olaylara adapte olmasında, bilinçli bir davranıştan ziyade, bedensel ve pratik mantık temelinde ortaya çıkan yatkınlıklar bütünüdür. Bir başka ifadeyle habitus, bireylerin içinde yaşadığı toplumsal hayatta herhangi bir zorlukla karşılaştığında, onu çözüme götüren bilgiler ve yatkınlıkların tümüdür (Görgün Baran \& Öksüz, 2011: 10).

Habitus, toplumsal sınıflar ile sportif pratikler arasındaki ilişkiyi anlamak ve yeni spor branşlarının ortaya çıkmasının ya da yayılmasının mantığını kavramak açısından önemlidir. Yeni bir sporun ortaya çıkışı ya da mevcut bir sporun yeni bir tarzda icra edilmesi, spor pratikleri uzamının yeniden değerlendirilmesine ve bir anlam değişikliği yaşandığından dolayı da, yeniden bir tanım yapılmasını gerektirir. Ancak, ortaya çıkan bu yeni durum, her üretim alanı gibi spor alanı da sportif pratiklere olan ihtiyacı üretmeye destek olsa da, yine de eyleyicilerin herhangi bir sportif pratiğe olan ilgisi, kendilerinin beden üzerinden kurdukları spora karşı yatkınlıkları, bu yatkınlıklar sisteminin bütünlüğüyle, yani yaşam tarzlarının temeli olan habitus ile ilişkilendirilmediği müddetçe anlaşılması 
mümkün değildir (Bourdieu, 2015b: 110). Spor alanının ya da sportif beğeninin tam alarak anlaşılabilmesi, ancak bireylerin sahip olduğu sınıf habitusunun göz önüne alınmasıyla mümkün olabilir. Sınıf habitusu, herhangi bir sportif pratiğin anlamının ve o pratikten elde edilecek kazanımların en temel belirleyicisidir.

Bireyler nesneleri, sahip oldukları habitus çerçevesinde değerlendirdikleri için, aynı faaliyete yükledikleri anlam da birbirinden farklı olacaktır. Dolayısıyla farklı habituslara sahip olan bireylerin, aynı sporu yapsalar bile, o sportif pratikten beklentileri ya da yapma biçimleri değişecektir (Bourdieu, 2015a: 308). Örneğin, habitusları farklı olan iki birey bilardo oynamak istediğinde, biri bilardo salonuna gidip oynarken, diğeri bilardo masasını evine alıp oynayacaktır.

Çeşitli pratiklerin sınıflara göre değişimi, sadece bireylerin iktisadi ya da kültürel bedellerini ödeme imkanları ile ilgili değil, aynı zamanda bu pratiklere katılarak elde edecekleri doğrudan ya da dolaylı getirilerle de ilişkilidir. Farklı habituslara sahip olan bireylerin, bazı sporlara katılmanın bireye sağladığı toplumsal getiriye atfettikleri önem aynı değildir. Örneğin golf sporuna katılmak, sporun sağlık işlevinin ötesinde, statü ve prestij gibi daha farklı anlamları intiva eder. Bu hemen herkesçe bilinen ve kabul edilen bir durumdur. Farklı habituslara sahip olanların, farklı sportif pratiklere eğilim göstereceğine dair herkesin temel bir bilgisi vardır (Bourdieu, 2016: 222).

Bir başka örnek, vücut geliştirme ve halter sporları için verilebilir. Kas geliştirme için yapılan vücut geliştirme ve halter sporu uzun bir zaman, halk sınıflarının popüler bir sporu olmuştur. Bundan dolayı, halter sporu uzun zaman olimpiyat yetkililerinden resmi kabul alamamıştır. Bunun temel nedeni, modern sporun aristokrat kurucularının zihninde halter, güç, hoyratlık ve entelektüel eksiklik anlamına gelmektedir. Dolayısıyla halk sınıflarına ait bir pratiktir (Bourdieu, 2016: 221-222). Bir başka ifadeyle bu örnek, habitusları farklı olanların sportif pratiklere bakışının da farklı olduğunun bir göstergesidir.

Bourdieu çalışmalarında, basketbol, hentbol, rugby ve futbol gibi takım sporları ile boks ve güreş gibi popüler olan bireysel sporların büro çalışanları, teknisyenler ve tüccarlar tarafından oynandığını tespit etmiştir. Ancak bu sporlar, egemen sınıfların kendilerini onlardan uzak tutacak birçok unsuru bünyesinde barındırmaktadırlar. Bunlar arasında kitlesel ya da popüler olmanın getirdiği bayağılık, mücadelenin kutsanması, güç, direnme, şiddet, kendini feda etme, yumuşak başlılık ve disipline itaat gibi unsurlar yer alır. Bütün bu hususlar egemen sınıfın temel erdemlerinin karşısında olan hususlar olduğunda dolayı, bu tür sporlardan uzak dururlar (Bourdieu, 2016: 223). Gerçekte egemen sınıflar ile diğer sınıflar arasındaki erdem farklılıkları, dolayısıyla bu farklııkların sportif pratiklerin seçiminde ortaya çıkan sonuçları, habitus farklılı̆̆ından kaynaklı olarak ortaya çıkmaktadır.

\section{Sermaye}

Insanların toplumsal hayatta tercih ettikleri tüm pratikler, sahip olduğu sermaye hacmi ve türüne bağlıdır. Insanların sahip olduğu beğenilerin de, bu sermayeler üzerinden ortaya çıktığı ya da farklılaştığı görülür.

Günümüz tüketim toplumunu anlamak için, tüketilen ürünlerin anlamlar dünyasını iyi analiz etmek gerekir. Buna göre, iktisadi olarak alınan bir ürün ya da tüketilen bir pratik, insanlar için sadece ekonomik bir faydanın aracı değildir. Ayrıca, insanın konumu ya da statüsü hakkında bilgi veren bir iletişim aracıdır (Featherstone, 2005: 143). Dolayısıyla, insanların sahip olduğu iktisadi sermaye ile birlikte, kültürel sermayenin de yaşam tarzı ve kültürel pratiklerin (beğenilerin) belirlenmesinde başat bir rolünün olduğu görülmektedir. Kültürel pratiklerdeki beğeni kalıpları aynı zamanda, sınıfsal bir göstergenin izlerini de taşımaktadır.

Spor, insanların genel olarak ya da çok yönlü bir şekilde bütün sermaye hacimlerini arttırır. Aile ya da okuldan kazanılan spor alışkanlığı ile kültürel sermayeyi, bir para kazanma aracına dönüşerek iktisadi sermayeyi, yeni insanlar tanıma ya da ilişkiler geliştirmeye ve yeni ortamlara girmeye olanak sağlayarak sosyal sermayeyi ve ulusal ya da uluslararası unvanlar ya da madalyalar kazanma fırsatı vererek simgesel sermayeyi arttırır (Giulianotti, 2005: 163). 
Bourdieu, "Ayrım" (2015a: 194-195, 322) isimli eserinde, müze ziyaretleri, konser ve okuma gibi yüksek kültürel pratiklerden yeme-içme, kıyafet, otomobil, gazete, hobi, spor ve serbest zamanı değerlendirmeye kadar, yaşam tarzı ve tüketim kalıpları üzerinden toplumsal alanın haritasını oluşturmaya çalışır. Bu eserinde spor ile ilgili kısımlar göz önüne alındığında, insanların sahip oldukları sermaye türlerine göre, sportif eğilimlerinin de değiştiği görülür. Buna göre, sermaye hacmi yüksek olanların golf ve briç gibi sporlara yöneldikleri, düşük olanların ise futbol ve rugby sporlarına ilgi duydukları görülmektedir. Araştırma bulgularına daha detaylı bakıldığında, ticaret patronları ve sermayeciler gibi iktisadi sermayesi yüksek olanların, tenis, su kayağı ve binicilik gibi sporlara katıldıkları, üniversite hocaları, sanat üreticileri ve ortaokul ve lise öğretmenleri gibi kültürel sermayesi yüksek olanların ise satranç, bisiklet, dağ sporları ve kır yürüyüşü yaptıkları görülmektedir. Vasıfsız, yarı vasıflı ve vasıflı işçiler gibi iktisadi ve kültürel sermayesi düşük olanlar ise, halk oyunları, futbol, rugby ve televizyondan spor müsabakalarını izlemektedirler.

iktisadi sermayenin golf, kayak, yelken, binicilik ve tenis gibi sportif pratiklerde önemli olmasına rağmen, salt iktisadi sermaye üzerinden bu pratiklerin sınıflar arasındaki dağılımını anlamak mümkün değildir. Bu sporların alt ve orta sınıflar için yukarı doğru dikey hareketliliğe kapalı ve elit tabakada da prestijin en temel göstergelerinden biri olmasında, aileden aktarılan değerler, erken yaşta katılım ve sosyalleşme süreci gibi daha çok kültürel sermayenin izleri görülmektedir (Bourdieu, 2015a: 318). Dolayısıyla, sadece iktisadi sermaye bazen sportif alanın haritasını analiz etmeye yetmemektedir.

Ayrıca, farklı sermayelere sahip olan bireylerin spordan beklentileri de farklı olmaktadır. Örneğin, iktisadi ve kültürel sermayesi yüksek olan ailelerin çocukları için, tenis ya da golf gibi sporlar dışında, spor üzerinden bir kariyer hedefi bulunmazken, düşük iktisadi ve kültürel sermayeye sahip ailelerin çocukları için spor, statü yükseltmenin bir aracı olabilmektedir (Bourdieu, 2016: 219-220).

Sermaye farklılıkları spor yapma amaçlarında da kendini göstermektedir. Genel sermaye hacimleri düşük olanların kaslarını güçlendirmek için - daha çok dış bedene yönelik- spor yaptıkları, sermaye hacimleri yüksek olanların ise, zarafet, rahatlama, güzellik, sağlık ve ruhsal denge gibi -daha çok iç bedene yönelik- amaçlarla spor yaptıkları görülmektedir (Bourdieu, 2016: 221).

Sosyal sermayenin kazanılmasındaki en temel husus sosyal ilişkilerdir. Bireylerin sosyal çevresi ne kadar geniş olursa, sosyal ilişkilerinin hacmi de bir o kadar fazla olur. Bu bağlamda spor, bireylerin yeni bir sosyal çevreye girmesine öncülük edebilmektedir. Spor aracılığıyla girilen yeni sosyal çevre, aynı zamanda yeni sosyal ilişkilerin kurulması anlamına gelmektedir (Bourdieu, 2015a: 308). Spor bilinçli ya da bilinçsiz insanların sosyal sermayelerini arttıran bir pratiktir (Dever, 2017: 235). Insanlar spor kulüplerine üye olarak ya da bir spor salonuna spor yapmaya giderek, yeni ilişkiler geliştirmekte, bir gruba ait olmakta ve yeni arkadaşlar kazanmaktadır. Bütün bu eylemler, spor aracılığıyla insanların sosyal sermayelerinin artmasına neden olur.

Günümüzde, gündelik hayatta tükettiğimiz ürünlerin işlevselliği artık ön planda değildir. Tüketim pratikleri farklı argümanlarla ilişkilendirilerek, simgesel bir anlam içeren metaya dönüştürülmüştür (Featherstone, 2005: 144). Bir anamda insanlar artık, simgelerin hakim olduğu bir dünyada yaşamaktadır. Dolayısıyla, spor yapmaya gidilen tesislerden, spor yaparken kullandığımız araç ve gereçlere kadar her birisinin simgesel anlamı vardır.

\section{Beden Anlayışı}

Bourdieu sosyolojisi, rasyonel eylem kuramının aksine, bireylerin sahip oldukları pratik bir mantık, sezgi ve bedensel yatkınlık ekseninde eylemlerini gerçekleştirdiklerini iddia eden ve bu çerçevede sosyal hayatta beden ile pratiklerin mantığına vurgu yapan bir sosyolojidir (Görgün Baran \& Öksüz, 2011: 4). Habitus bireylerin bedenleri üzerinden, konuşma, yürüme, davranma ve yemek yeme biçimleri gibi eylemleri yapılaştırır. Dolayısıyla habitus, beden ile iç içe geçmiş bir yapı olarak karşımıza çıkar (Elliott, 2017: 195). Bir diğer ifadeyle, bütün bedensel pratiklerimiz sahip olduğumuz habitusun bir yansıması ya da beden sınıfsal beğeninin vücuda bürünmüş halidir. 
Bireylerin tüm seçkinlik arayışları dışında, alt tabakayı üst tabakadan ayırt eden ve üst tabakanın içinde de yaşam tarzı farklılıklarını ortaya çıkaran husus, habitusun ayrıcalıklı boyutu olan bireyin kendi bedeni ile kurduğu ilişkidir.

Bedene bürünen ya da beden üzerinden nesneleştirilen birtakım özellikler, bir anlamda karşımızdakilerle iletişim kurduğumuz bir dile dönüşür. Bu dil, kendisinin konuşulmasından ziyade insanı, bedeni üzerinden konuşur. İnsanların arasındaki eşitsizlik, simgesel bir sisteme de atıf yapar ve insanların sahip olduğu otomobil, yaşadığı mekan ya da ev, yaptığı sporlar gibi çeşitli simgeler, onu diğerlerinden ayıt edici göstergeler olarak işlev görür (Bourdieu, 2014: 200).

Elit tabakanın bedenini çok rahat kullandığı, bedeniyle barışık olduğu ve elit tabakada bedenin amaç olduğu görülmektedir. Alt tabaka için ise beden rahatsızlık duyulan bir nesne, gösterge değeri olan bir varlık ve daha da önemlisi bir takım amaçlara ulaşmak için araç olarak görülen bir nesnedir. Bu anlayışın sportif pratikler üzerinde de yansımaları vardır.

Beden ile kurulan ilişkinin farklılığını güreş ve aikido üzerinden takip etmek mümkündür. Bu branşlara ilk bakıldığında dahi bu farklıııklar çok net bir şekilde görülebilir. Örneğin, güreşte beden bedene rekabet, sert ve direkt bedensel bir temasın göstergesi iken, ayakta yapılan bir mücadele sporu olan aikido da ise temas geçici ve belli bir mesafeye dayanır. Güreş ile aikido arasındaki bu farklılı̆ı̆n anlamının kolayca görülmesinin sebebi, bayağı, erkeksi, beden bedene, doğrudan vb. ile havalı, hafif, mesafeli, kibar arasındaki karşıtlığın, spor alanının ve iki branşın zıtlığının sınırlarının ötesinde bir anlama sahip olmasıdır. Bu sporlar arasındaki farklılı̆ın temelinde beden ile kurulan ilişki farklılı̆ı vardır. Bir diğer ifadeyle toplumsal konum farklılığı beden ile ilişkinin de en temel belirleyicisidir. Buna göre, bireyleri birbirinden ayıran pratikler, rakip ile en mesafeli ilişkiyi kuranlardır ve en estetik olan pratikler de yine bu özellikleri taşıyan pratiklerdir (Bourdieu, 2013: 254-255). Dolayısıyla, elit tabakada amaç olan beden aikidoya, alt tabakada araç olan beden güreşe yönelmektedir.

Farklı toplumsal sınıfların, kimilerinin kaslarını geliştirmek için çeşitli pratiklere yönelerek dış beden üzerine odaklanması, kimilerinin ise, zarafet, güzellik, sağlık ve zihinsel uyum gibi hem iç hem de dış beden ile ilgili pratiklere ilgi göstermesi, bir sportif pratiğin etkileri konusunda farklı düşündüklerini göstermektedir (Bourdieu, 2105b: 112).

Farklı sınıfların katıldığ sportif pratiklerden beden ile ilgili beklentilerinin aynı olmadığı görülmektedir. Örneğin dış bedenin geliştirilmesinden haz duyan halk kesimleri, jimnastik sporuna güçlü bir beden yaratmak amacıyla katılırken, esas olarak bedenin sağlığı ile ilgilenen burjuvazi ise, jimnastik aracılığıyla sağlıklı bir bedene ulaşmak için bu sporu yapmaktadır (Bourdieu, 2016: 221). Bu durum, aynı zamanda yukarıda ifade edilen araçsal beden anlayışının bir yansıması olarak değerlendirilebilir.

Bireylerin iktisadi veya kültürel sermayeleri ve habitusları çerçevesinde sportif pratiklere olan eğilimlerinin farklılaştığı açıktır. Ayrıca bireyin sahip olduğu sermaye hacmi veya habitusu ekseninde bedeni ile kurduğu ilişki de değişmektedir. Buna göre, sermaye hacimleri düşük olan halk sınıflarının bedenleriyle, bedeni ön plana çıkaran pratiklerle kurduğu araçsal ilişki, yüksek efor gerektiren, ağrı ve acı veren, bünyesinde çeşitli tehlikeleri barındıran boks ve bizzat bedenin varlığını tehlikeye atan motosiklet, paraşüt, akrobasi ve dövüş sporlarına olan eğilimde açığa çıkar (Bourdieu, 2015a: 311312).

Diğer taraftan, bir sportif pratiğinin elit tabaka pratiği olabilmesi için, o spor pratiği icra edilirken bedenin kullanım şekli, bireyin onuruna, haysiyetine ya da şerefine zarar getirmemesi gerekir. Örneğin, rugby gibi mücadele yoğun sporlardaki oyuncuların bedenini ortaya koyması ya da atletizmde, özellikle bazı dallarında, bedenin sınırlarının zorlanması gibi hususlar, dolayısıyla genel anlamda bedenin yoğun olarak kullanıldığı sporlar burjuvalar için cazip değildir. Burjuvalar için beden, herhangi bir mücadelede ve çeşitli hedefler için bir araç olmaktan ziyade, bizzat kendisi amaçtır ve rahatlığın göstergesidir (Bourdieu, 2015a: 319). Bu analizler ekseninde, bireylerin sermayeleri ya da habitusları ekseninde bedene yaklaşım tarzlarının değiştiği söylenebilir. 


\section{Beğeni Yargısı}

Bugün insanların en temelde ayrıştıkları noktaların başında beğenileri gelir. İnsanların sahip olduğu maddi ürünler ya da katıldığı etkinliklerin hemen hepsi bir beğeni göstergesi şeklinde değerlendirilir. Ev, araba, kıyafet, spor gibi bütün yaşam tarzı pratikleri, insanların beğeni yargıları ile eş değer görülür (Featherstone, 2005: 145). Bir diğer ifadeyle, beğenilerimizle var olduğumuz ya da beğenilerimizin konuştuğu bir dünyada yaşamaktayız.

Beğeni, insanların sosyal sınıfına göre farklılaşmaktadır. Bourdieu’ye göre sosyal sınıfların sahip olduğu beğeniler, sınıfların yaşam tarzlarının bir göstergesi ve bütün eğilimlerinin en temel belirleyicisidir. Dolayısıyla yaşam tarzı farklılıklarının yansıması olarak, spor ile ilgili bütün pratiklerimiz (katılım oranı, katıldığımız sporlar, spor yaptığımız mekanlar, spor yaparken giydiğimiz kıyafet ve kullandığımız araç-gereçler ve spor yapma amaçları) ve beden ile ilişki kurma tarzımız, beğenilerimiz çerçevesinde şekillenir ya da anlam bulur (Molnar \& Kelly, 2013: 76).

Alt tabakanın üst tabakanın beğenilerini taklit etmesi ya da onlara özenmesi, elit tabakanın alt tabaka ile arasındaki farklıkları ya da mesafeyi sabit tutacak yeni beğenilere yönelmesine neden olur. Bir diğer ifadeyle, elit tabakanın pratikleri, orta ve alt tabakaya doğru yayıldıkça, elit tabaka yeni pratiklere yönelir ve yeni pratiklerle bu beğeni farklılığını devam ettirmek ister (Featherstone, 2005: 149). Spor alanı da bu beğeni farklılıklarını izlenebileceği bir alandır (Jarvie \& Maguire, 2002: 200; Ünal, 2017: 387).

Bourdieu (2015a: 311), üst sınıflara özgü pratiklerin, toplumun geri kalanına doğru yayılmasını demokratikleşme kavramı ile açıklar. Bundan dolayı sporun demokratikleşmesi de elit sınıfın sportif pratiklerinin orta ve alt tabakaya yayılması anlamına gelir. Dolayısıyla demokratikleşme sürecinde olan sporlar, tarihsel süreçte farklı yerlerde ve zamanda toplumun farklı kesimleri ile karşılaşırlar. Ancak bu karşılaşma bireylerin beğenileri ekseninde farklı bir şekilde gerçekleşir. Örneğin, her sportif pratiğin kendine özgü, kuralları, araç-gereçleri, kıyafetleri vardır. Tenis örneğinden hareketle, bu sporu uzun zamandır icra eden ve icra ederken uygun kıyafetler giyen (Lacoste gömlek, beyaz şort veya etek ve özel ayakkabılar) ve tenisin sahip olduğu değerlere diğerlerinden daha fazla özen gösteren özel bir kulübün üyesi olan bireylerle, tenisi belediye ve tatil kulüplerinde yeni yapmaya başlayanların, tenise özgü kıyafetleri bu sporun basit bir ritüeli olarak görmeyenlerle her açıdan karşı karşıya oldukları görülmektedir. Bir diğer ifadeyle, altta bermuda şort, üstte sıradan bir tişörtle veya normal bir adidas ayakkabı ile oynanan tenis, hem oyun sırasındaki oyuna özgü davranışlar hem de alınan haz açısından aynı tenis değildir.

Fransa'da popüler sporlardan futbol, rugby, güreş ve boks branşları ekseninde de bu hareketlilik izlenebilir. Bu sporlar önceleri aristokrat ya da soylulara ait pratiklerken, halk kesimlerinde yaygınlaşarak, daha önce soylu pratikleri iken sahip oldukları değerlerden uzaklaşmışlardır. Soylulara ait pratikler oldukları zamanlarda, müsabakanın yüceltilmesinden, halk kesimlerinde yaygınlaştığında güç, kötüye direnme, itaatkarlık gibi birtakım yeni değerlere doğru bir anlam kayması yaşanmaktadır (Bourdieu, 2015a: 315). Görüldüğü üzere, herhangi bir sporun elit tabakadan alt tabakaya doğru yayılması, beğeni farklılı̆ından dolayı, o sportif pratiğin yaygınlaştığı geniş kitlelere ait yeni değerlerle donanması ve icra edilmesi anlamına gelmektedir.

Egemen beğeniye ait ayrıştıııcı özellikler golf, tenis, yelken, binicilik, kayak ve eskrim gibi sporlar özelinde daha da belirginleşir. Bu pratikler sadece imtiyazlı kişilerin girebileceği yerlerde, yalnız ya da daha önceden belirlenmiş bir eşle yapılan, belli bir süre devam ettirilen ve özgürce seçilen pratiklerdir. Aynı zamanda, belirli kurallar ile birlikte fair play anlayışı çerçevesinde müsabakalar yapılır. Bu kapsamda bu pratikler hiçbir fiziksel ya da sözel şiddetin olmadığı, bedenin bütün aykırı kullanımlarının yasaklandığı ve özellikle de her türlü temasın engellendiği en üst seviyede uygarlık göstergesine dönüşmüş pratiklerdir. Ayrıca, yelken, kayak ve rüzgar sörfü gibi sporların temelinde, yüzyıllardır sporun en temel öğesi olan rakibe karşı mücadelenin ya da erkek erkeğe müsabakanın yerine, doğa ile mücadele yer alır (Bourdieu, 2015a: 316-317). 
Beğeni farklılıkları neticesinde ortaya çıkan bireyler arasındaki toplumsal mesafe, spor alanında da çok somut bir şekilde ortaya çıkmaktadır. Örneğin, golf dünyanın her yerinde, çevrili bir alanda, özenle düzenlenmiş bir saha aracılığıyla, bu spora katılma imkanı olmayanlarla arasına bir mesafe koymaktadır. Ayrıca bu sporun icrasında top ile teması saymazsanız, her türlü temas dışlanır (Bourdieu, 2013: 255).

\section{Değerlendirme ve Sonuç}

Bourdieu, dikkat çekici bir yukarı yönlü dikey hareketlilik örneği olan hayatı ve en çok atıf alan sosyologlar arasında ilk sıralarda yer alan ve kimi eserlerinin sosyoloji klasikleri arasına girdiği entelektüel çizgisi, daha önce ortaya konulan düşüncelere getirdiği eleştiriler ve onların eksikliklerini gidererek geliştirdiği kendine özgü sosyolojisi, alana kazandırdığı yeni kavramları ve bu kavramlar ekseninde farklı disiplinlerden teorisyenlere de yeni çalışma alanları oluşturan, XX. yüzyılın en önemli sosyologlarından biridir.

Bourdieu'nün hayatı, alt orta bir sosyo-ekonomik statüden, en azından kültürel sermaye açısından üst tabakaya doğru, istikrarlı şekilde tırmanan bir başarı hikayesidir. Felsefe ile başlayan, antropoloji ile devam eden ve nihayetinde sosyolojide kendini gösteren entelektüel hayatı boyunca, hem nitelik hem de nicelik açısından oldukça önemli çalışmalara imza atmıştır. Çok yönlü bir sosyolog olarak, hemen her eserinin konusu birbirinden farklı olan, yaşadığı dönemin temel sorunlarına dikkat çekmeyi başarabilen ve çok farklı konular üzerinde eserler üretmiş bir sosyologdur. $\mathrm{O}$, bireylerin davranışlarının altında yatan temel dinamikleri, ürettiği kavramlar ve derinlemesine yaptığı saha araştırmaları ile ortaya çıkarmaya çalışmıştır. Bir diğer ifadeyle, özel olandaki geneli görmeyi sağlayan çalışmaları ve eserleri ile sosyoloji dünyasında haklı bir üne olmuş ve eserleri birçok bilim insanına farklı bir pencere açmıştır.

Sosyolojiye önemli kuram ya da kavramlar kazandıran Bourdieu, sosyolojisini ya da sosyolojik bakışını hem klasik sosyologlardan hem de daha önceki kuramlardan ayırmayı başarmış, onlar üzerine yeni bakış açıları geliştirmiş ve ortaya attığı yeni kavram ya da kuramlarla kendine özgü bir sosyolojik perspektif geliştirmiştir. Bourdieu, her sosyolog gibi ve doğal olarak, kendi sosyolojik bakışının doğruluğunu oldukça katı bir şekilde savunan ve kendi döneminde ya da öncesinde yaşayan sosyologların düşüncelerini sert bir şekilde eleştirerek, hatta Touraine gibi ünlü bir sosyolog için dahi "ya onun yaptığı sosyoloji değil ya da benimki" diyerek, bu tavrını göstermiştir (Amman, 1995: 115).

Bourdieu'nün değeri ya da önemi, sosyolojiye kazandırdığı kavram, kuram ve eserlerin yanında, bu kuram ya da kavramların ampirik çalışmalarla derinlemesine analizinin yapılarak, pratikte karşılıklarını göstermesiyle ilişkilidir. $\mathrm{O}$, pratiği olmayan teorik yaklaşımı benimsememiş ve muhakkak ortaya attığı teoriyi anket yöntemi ve zengin istatistiki verilerle ispat etme yoluna gitmiştir. Dolayısıyla alan, sermaye ve habitus gibi kavram ya da teoriler böyle bir yaklaşımın ürünü olarak ortaya çıkmıştır. Bu kavramlar üzerinden toplumsal yaşamdaki farklılıkların analizi ya da ortaya çıkarılmasında, saha araştırmalarının önemli bir etkisi vardır. Ayrıca, beğeni yargısı ve beden üzerine de analizler yapan Bourdieu, beğeni farklılıkların ya da beden ile ilgili pratiklerin insanların sahip olduğu habitus ya da sermaye ekseninde ortaya çıktığını tespit etmiştir.

İnsanların katıldığı bütün kültürel pratikler, habitusları ekseninde şekillenmektedir. Ayrıca gerek iktisadi, gerek kültürel, gerekse sosyal sermaye ve bunların birleşimi sonucunda ortaya çıkan simgesel sermaye, toplumsal hayatta bütün bireyler arasında eşit bir şekilde dağılmamıştır. Bundan dolayı, insanların habituslarının ve sermaye hacimlerinin farklıı̆ı̆ı, toplumsal yaşamda birtakım eşitsizlikleri gündeme getirmektedir. Bu eşitsizlikler, toplumsal kurumlardan biri olan spor alanında da kendini gösterir. Bir diğer ifadeyle, habitus ve sermaye farklılığı, bireylerin sportif pratiklere katılımlarındaki farklılıkları da beraberinde getirir.

Bourdieu alan teorisinden yola çıkarak, spor alanının da kendine özgü bir tarihinin olduğunu söyler. Tarihsel süreç içerisinde spor alanı da kendi kurallarını, dinamiklerini ve sınırlarını belirlemiştir. Dolayısıyla, spor alanında oynanan bu oyunun temel dinamiklerini anlayabilmek için, oyuna bütüncül 
bir tarihsel bakışla yaklaşmak gerektiğini ifade eder. Ayrıca, habitusun tarihsel bir boyutunun da olması, spor alanında ortaya çıkan bireysel ya da kolektif eylemlerin, ancak bu tarihsel bakış açısıyla anlaşılabileceğini savunmaktadır. Bu bakış açısı, bireyselin arkasındaki toplumsalı, spor üzerinden de görme fırsatı verir.

Bourdieu, insanların seçtikleri spor branşlarının (golf ya da futbol), katıldıkları spor türünün (takım sporları ya da bireysel sporlar), spora katılım şeklinin (aktif ya da pasif), spor yapma amaçlarının (sağlık ya da para), spor yaparken giydiği kıyafetlerin (şort/eşofman ya da günlük kıyafet), spor yaptığı tesislerin (otelde ya da semt sahasında) ve daha birçok sportif eğilimin sahip oldukları habitus ve sermaye ekseninde şekillendiğini, yaptığı saha çalışmalarıyla çok net bir şekilde ortaya koymuştur.

Bazı teorisyenler (Malcolm, 2012: 44-45) spor ve Bourdieu sosyolojisi arasındaki ilişkiyi sorgulamaktadırlar. Bu soruların temelinde, Bourdieu sporun sosyolojisini mi yapmıştır ya da spor aracılı̆ııla sosyoloji mi yapmıştır? gibi sorular yer alır. Farklı sportif etkinliklere yüklenen anlamın metodolojik olarak çözümlenmesi, bireylerin katıldıkları spor etkinlikleri üzerinden, birtakım sosyolojik özellikleri belirlemeye imkan verir (Bourdieu, 2015a: 308). Dolayısıyla Bourdieu, spor üzerinden sosyolojik analizler yaparak, hem toplumsal alanın anlaşılmasına olanak sağlamış hem de spor sosyolojisinin gelişmesine önemli bir katkı sunmuştur.

Bourdieu, spor sosyolojisinin sosyologlar tarafından göz ardı edildiğini, sporcular tarafından ise, küçümsendiğini söylemektedir. Bir taraftan elit sporcu olarak, sporun iyi bir uygulayıcısı fakat teorisi hakkında hiçbir fikri olmayan, diğer taraftan spor hakkında kuramsal boyutta konuşabilen, ancak spor yapmayan ya da bilinçsizce yapan insanlar vardır. 0 , bir spor sosyolojisinin oluşabilmesi için, salt bir branş üzerinden gidilerek, spor pratiklerinin genel mantığını anlamadan yapılacak çözümlemelerle, bir spor sosyolojisinin oluşturulamayacağını düşünmektedir. Ona göre, "spor pratikleri uzamının her öğesi ayırıcı özelliğe sahip bir sistem olarak" düşünülmesi gerekir. Bir diğer ifadeyle, hangi spor türü olursa olsun, bir sportif pratiği anlamak için, spor uzamındaki konumunu iyi bilmek gerekir. Bu uzam, bir taraftan bireylerin toplumsal konumlarına göre spor alanındaki dağılımı vb., diğer taraftan bizzat uygulayıcısı olduğu spor üzerinden kurduğu beden ilişkisi çerçevesinde oluşturulabilir. Daha sonra bu spor uzamını, kendisini spor pratiğini icra ederken ortaya çıkaran toplumsal uzam ile ilişkilendirmek gerekir. Bu yaklaşım insanları, spor ile onun uygulayıcıları arasındaki kurulabilecek hatalı ilişkilerden koruyacaktır. Ona göre sosyoloğun işi, herhangi bir spor türünü toplumun belli bir kesiminin beğenileri ya da tercihleri ile uyumlu hale getiren toplumsal açıdan anlamlı olan özelliklerini tespit etmektir (Bourdieu, 2013: 254).

Sonuç olarak, Bourdieu, hayatı, eserleri, sosyolojisi ve geliştirdiği teori ve kavramları ile sosyoloji dünyasına ismini başarılı bir şekilde duyurmuş bir sosyologdur. Ayrıca, hem eski bir rugby oyuncusu olarak sporu bilen birisi olması hem de bir sosyolog olarak sporu analiz etmesi, spor sosyolojisini gelişiminde tartışılmaz bir katkısı olmuştur.

\section{Kaynaklar}

Amman, MT. (2006). Kitle Sporunun Toplumsal Dinamikleri. İstanbul: Çamlıca Yayınları.

Amman, MT. (2000). Spor Sosyolojisi. H. Can İkizler (Ed.). Sporda Sosyal Bilimler içinde (85-151). İstanbul: Alfa Yayınları.

Amman, MT. (1995). Sosyal Tabakalaşma ve Günümüz Fransız Sosyolojisinin Yaklaşımları. (Yayımlanmamış Yüksek Lisans Tezi). İstanbul Üniversitesi Sosyal Bilimler Enstitüsü, İstanbul.

Arslantürk, Z., Amman, MT. (2012). Sosyoloji-Kavramlar, Kurumlar, Süreçler, Teoriler. 8. Baskı. İstanbul: Çamlıca Yayınları.

Bourdiue, P. (2016). Sosyoloji Meseleleri. Çev: Filiz Öztürk, Büşra Uçar, Mustafa Gültekin, Aslı Sümer. Ankara: Heretik Yayınları. 
Bourdieu, P. (2015a). Ayrım-Beğeni Yargısının Toplumsal Eleştirisi. Çev: Derya Fırat, Günce Berkkurt. Ankara: Heretik Yayınları.

Bourdieu, P. (2015b). Spor ve Toplumsal Sınıf. İlknur Hacısoftaoğlu, Funda Akcan, Nefise Bulgu (Ed.). Oyunun Ötesinde-Spor Sosyolojisi Çalışmaları içinde (95-119). Ankara: Notabene Yayınları.

Bourdieu, P., Passeron, JC. (2014). Varisler: Öğrenciler ve Kültür. Çev: Levent Ünsaldı, Aslı Sümer. Ankara: Heretik Yayınları.

Bourdieu, P., Wacquant, L. (2014). Düşünümsel Bir Antropoloji Iç̧in Cevaplar. 7. Baskı. Çev: Nazlı Ökten. İstanbul: İletişim Yayınları.

Bourdieu, P. (2014). Simgesel Sermaye ve Toplumsal Sınıflar. Cogito, 76: 192-204.

Bourdieu, P. (2013). Seçilmiş Metinler. Çev: Levent Ünsaldı. Ankara: Heretik Yayınları.

Bourdieu, P. (2010). Vive La Crise!: Sosyal Bilimde Heterodoksi İçin. 2. Baskı. Güney Çeğin, Emrah Göker, Alim Arlı, Ümit Tatlıcan (Der.). Ocak ve Zanaat-Pierre Bourdieu Derlemesi içinde (33-53). İstanbul: Illetişim Yayınları.

Bourdieu, P. (2006). Pratik Nedenler-Eylem Kuramı Üzerine. 2. Baskı. Çev: Hülya Uğur Tanrı̈ver. İstanbul: Hil Yayınları.

Bourdieu, P. (1999). Sanatın Kuralları. Çev: Necmettin Kamil Sevil. İstanbul: Yapı Kredi Yayınları.

Calhoun, C. (2010). Bourdieu Sosyolojisinin Ana Hatları. 2. Baskı. Güney Çeğin, Emrah Göker, Alim Arlı, Ümit Tatlıcan (Der.). Ocak ve Zanaat-Pierre Bourdieu Derlemesi içinde (77-131). İstanbul: İletişim Yayınları.

Coakley, JJ. (1998). Sport in Society: Issues and Controversies. Sixth Edition. Boston: McGraw-Hill.

Corcuff, P. (2010). Habitustan Hareketle: Kolektife Meydan Okuyan Tekil. 2. Baskı. Güney Çeğin, Emrah Göker, Alim Arlı, Ümit Tatlıcan (Der.). Ocak ve Zanaat-Pierre Bourdieu Derlemesi içinde (367397). İstanbul: Illetişim Yayınları.

Çelik, Ç. (2014). Sosyal Sermaye, Ebeveyn Ağları ve Okul Başarısı. Cogito, 76:265-290.

Dever, A. (2017). Sosyolojik Teoriler ve Spor. Konya: Çizgi Kitapevi Yayınları.

Elias, N., Dunning, E. (2008). Quest for Excitement: Sport and Leisure in the Civilising Process. Dublin: University College Dublin Press.

Elliott, A. (2017). Çağdaş Sosyal Teoriye Giriş. Çev: Gaye Gökalp-Yılmaz. Ankara: Dipnot Yayınları.

Evren, C. (2018). Sporun Antropolojisi. Ayfer Bartu Candan, Cenk Özbay (Haz.). Kültür Denen ŞeyAntropolojik Yaklaşımlar içinde (233-256). İstanbul: Metis Yayınları.

Featherstone, M. (2005). Postmodernizm ve Tüketim Kültürü. 2. Baskı. Çev: Mehmet Küçük. İstanbul: Ayrıntı Yayınları.

Giulianotti, R. (2005). Sport: A Critical Sociology. Cambridge: Polity Press.

Göker, E. (2010). Ekonomik İndirgemeci mi Dediniz?. 2. Baskı. Güney Çeğin, Emrah Göker, Alim Arlı, Ümit Tatlıcan (Der.). Ocak ve Zanaat-Pierre Bourdieu Derlemesi içinde (277-303). İstanbul: İletişim Yayınları.

Görgün Baran, A., Öksüz, C. (2011). Pratik, Kültür, Sermaye, Habitus ve Alan Teorileriyle Pierre Bourdieu Sosyolojisi. Serap Uğur, Aylin Görgün Baran (Ed.). Sosyolojide Yakın Dönem Gelişmeler içinde (2-22). Eskişehir: Anadolu Üniversitesi Yayınları.

Jarvie, G., Maguire, J. (2002). Sport and Leisure in Social Thought. London and New York: Routledge.

Jourdan, A., Naulin, S. (2016). Pierre Bourdieu'nun Kuramı- Sosyolojik Kullanımları. Çev: Öykü Elitez. ìstanbul: Illetişim Yayınları. 
Kaplan, Y., Akkaya C. (2013). Toplumsal Tabaka Farklılıkların Spora Yansıyan Sonuçları (Antalya Örneği). Mediterranean Journal of Humanities, III/2: 143-158.

Malcolm, D. (2012). Sport and Sociology. London: Routledge.

Marshall, G. (2005). Sosyoloji Sözlüğü. 2.Baskı. Çev: Osman Akınbay, Derya Kömürcü. Ankara: Bilim ve Sanat Yayınları.

Molnar, G., Kelly, J. (2013). Sport, Exercise and Social Theory. Abingdon: Routledge.

Ritzer, G., Stepnisky, J. (2013). Çağdaş Sosyoloji Kuramları ve Klasik Kökleri. Çev: Irmak Ertuna Hawison. Ankara: De Ki Basım Yayım.

Ritzer, G. (2013). Sosyoloji Kuramları. Çev: Himmet Hülür. Ankara: De Ki Basım Yayım.

Sunar, L. (2018). Sosyal Tabakalaşma-Kavramlar, Kuramlar ve Temel Meseleler. Ankara: Nobel Akademik Yayıncılık.

Swartz, D. (2011). Kültür ve Iktidar-Pierre Bourdieu'nün Sosyolojisi. Çev: Elçin Gen. İstanbul: illetişim Yayınları.

Taarruz (2013). Eğlendirerek Hükmetmek -Halklara Karşı Kitle Kültürü. Çev: Yusuf Polat. Ankara: Heretik Yayınları.

Tatlıcan, Ü., Çeğin, G. (2010). Bourdieu ve Giddens: Habitus ve Yapının İkiliği. 2. Baskı. Güney Çeğin, Emrah Göker, Alim Arlı, Ümit Tatlıcan (Der.). Ocak ve Zanaat-Pierre Bourdieu Derlemesi içinde (303367). İstanbul: Illetişim Yayınları.

Ünal, AZ. (2018). Toplumda Tabakalaşma ve Hareketlilik-Olgular, Kavramlar, Kuramlar. 4. Baskı. Ankara: Atıf Yayınları.

Ünal, AZ. (2017). Bourdieu’nün Tabakalaşma Teorisi Bağlamında Üst Sınıftan Alt Sınıfa Doğru Hayat Tarzı Tahhakümü. Uluslararası Sosyal Araştırmalar Dergisi, 10 (49): 380-388.

Wacquant, L. (2012). Ruh ve Beden-Acemi Bir Boksörün Defterleri. Çev: Nazlı Ökten. İstanbul: Boğaziçi Üniversitesi Yayınları.

Wacquant, L. (2010). Pierre Bourdieu: Hayatı, Eserleri ve Entelektüel Gelişimi. 2. Baskı. Güney Çeğin, Emrah Göker, Alim Arlı, Ümit Tatlıcan (Der.). Ocak ve Zanaat-Pierre Bourdieu Derlemesi içinde (5377). İstanbul: İletişim Yayınları.

Yılmaz Anatca, V., Yılmaz, C. (2019). Ucube Bedenden Paralimpik Bedene. SDÜ Fen-Edebiyat Fakültesi Sosyal Bilimler Dergisi, 46: 136-157.

Yüksel, M. (2018). Sporda Sınıf illişkileri. Tarih Okulu Dergisi, XXXV: 344-365.

Yüksel, M. (2012). Sosyal Tabakalaşma ve Spor Iliş̧kisi (İstanbul Örneği). (Yayımlanmamış Doktora Tezi). Marmara Üniversitesi Sağılık Bilimleri Enstitüsü, İstanbul. 